\title{
The Horizontal Slab beneath East Asia and Its Subdued Surface Dynamic Response
}

\author{
Shaofeng Liu ${ }^{1}$, Pengfei Ma ${ }^{2}$, Bo Zhang ${ }^{1}$, Michael Gurnis ${ }^{3}$ \\ ${ }^{1}$ State Key Laboratory of Geological Processes and Mineral Resources and School of \\ Geosciences and Resources, China University of Geosciences, Beijing 100083, China. \\ ${ }^{2}$ Department of Earth Science and Engineering, Taiyuan University of Technology, Taiyuan, \\ Shanxi 030024, China. \\ ${ }^{3}$ Seismological Laboratory, California Institute of Technology, Pasadena, CA 91125, USA.
}

Corresponding author: Shaofeng Liu (shaofeng@ cugb.edu.cn)

\section{Key Points:}

- Trench-trench-trench triple junction shift-induced tearing of the Pacific slab and contributed to shaping the horizontal slab

- The dynamic topography fits with variation in residual subsidence by approximately \pm 200 meters over the last $50 \mathrm{Myr}$

- The subdued topography of East Asia was a response to stagnant slabs in the mantle

This article has been accepted for publication and undergone full peer review but has not been through the copyediting, typesetting, pagination and proofreading process, which may lead to differences between this version and the Version of Record. Please cite this article as doi: 10.1029/2020JB021156.

This article is protected by copyright. All rights reserved. 


\begin{abstract}
The kinematics of plate tectonics, deformation, and dynamic topography are strong indicators of coupling between plates and the mantle. East Asia is characterized by the presence of an unusually large horizontal slab that lies within the mantle transition zone. How this feature evolved and is linked to plate tectonics, deformation and topography is poorly understood. Here, we show four-dimensional geodynamic modeling results constrained by a new deforming plate reconstruction that fits mantle architecture inferred from seismic tomography. We find that the subducted western Pacific slab was progressively torn by the Philippine Sea plate rotating clockwise during the Miocene and that northwestward mantle flow contributed to shaping the horizontal slab during subduction, leading to dynamic subsidence along the East Asia margin. The rather subdued change in dynamic topography, predicted from those models that fit the horizontal slab in the mantle, is consistent with the variation in residual topography, recorded in the stratigraphy, within only about \pm 200 meters over the last $50 \mathrm{Myr}$ during a period of no large marine inundation or retreat. The tectonics and topography of East Asia strongly contrast with those of Southeast Asia and are reflective of slabs ephemerally stagnating in the mantle below East Asia while avalanching into the lower mantle below Southeast Asia.
\end{abstract}

\title{
1 Introduction
}

The deforming plate motion and dynamic topography are strong indicators of the coupling between plates and the mantle (Flament et al., 2014; Yang et al., 2016; Liu et al., 2017; Ma et al., 2019). The present-day subducted slab architecture in the mantle, as inferred from seismic tomography, records tectonics throughout geological time. Deforming plate reconstructions and residual topography are emerging as useful constraints on time-dependent plate-mantle dynamics. East Asia (Figure 1) has experienced long-term subduction with complicated interactions between multiple plates since the Mesozoic (Liu et al., 2017). The connection between deforming plate motion and dynamic topography on the Earth's surface and plate subduction in the mantle, the temporal plate tectonic history and three-dimensional plate tectonic architecture and heterogeneities deep in the mantle have remained elusive. Formulating a series of mantle flow models constrained by updated deforming plate reconstructions and residual topography may therefore hold the key to reproducing the present-day distinctive mantle architecture beneath East Asia while documenting how the coupled plate-mantle system is evolving and how the dynamic topography records mantle processes.

East Asia has experienced long-term subduction with complex interactions between Eurasia (EUR), the Philippine Sea (PSP), and the Pacific (PAC) Plates since the Mesozoic (Liu et al., 2017) and has developed a typical trench-trench-trench (TTT) triple junction system (Ma et al., 2019; Liu et al., 2017). The Izu-Bonin-Mariana (IBM) subduction zone, Japan subduction zone, and Nankai Trough-Ryukyu Trench join near the Boso Peninsula in central Japan. The Cenozoic tectonic history of East Asia was reconstructed based on a variety of observations (Zahirovic et al., 2016; Wu et al., 2016), but most of the earlier models have no TTT migration or different migration as the PSP evolves (Zahirovic et al., 2016; Wu et al., 2016; Ma et al., 2019), with rigid plate reconstruction (e.g., Ma et al., 2019). Therefore, we will use a reconstruction that incorporates TTT migration while combining more geological and geophysical observations from East Asia in a detailed deforming plate reconstruction. The new

This article is protected by copyright. All rights reserved. 
approach better depicts the evolving plate boundaries and plate deformation in models that we test with topographic constraints.

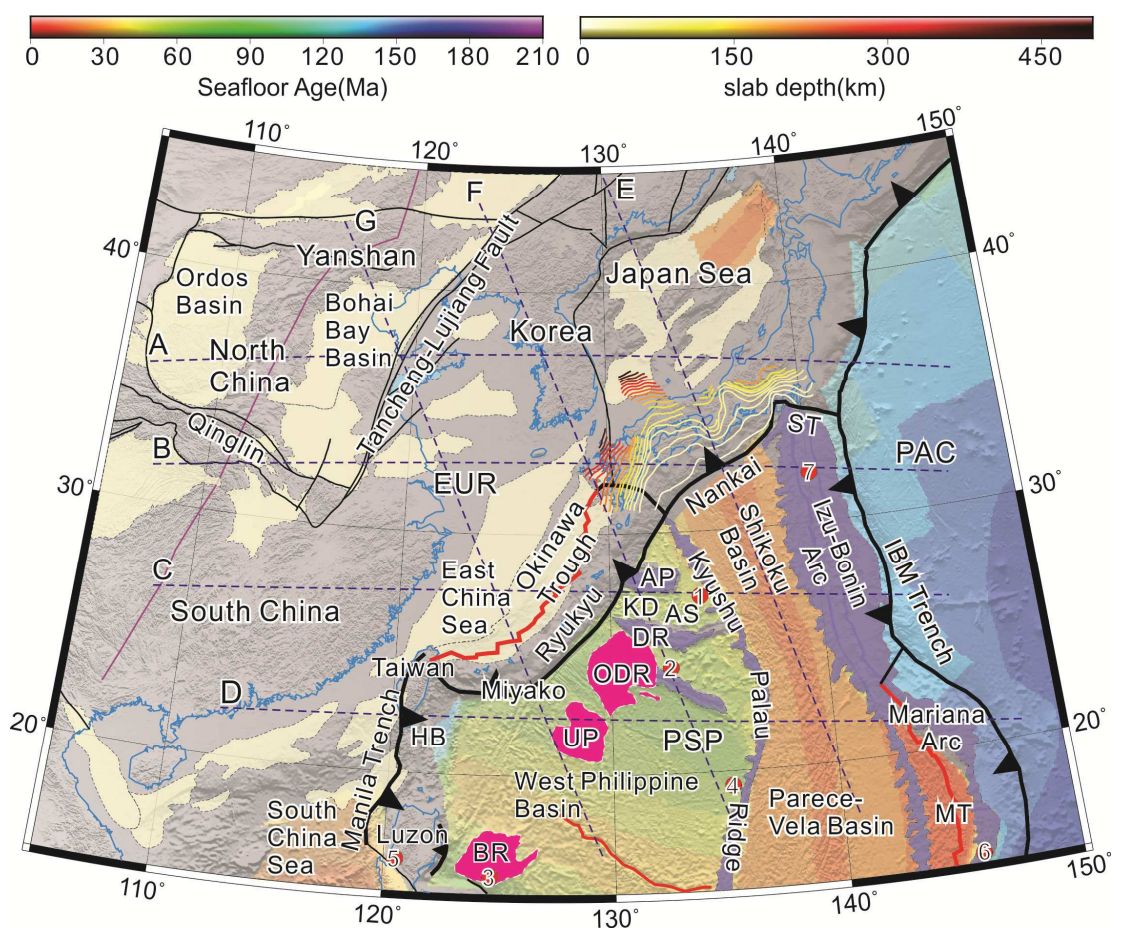

Figure 1. East Asia tectonic map. The morphology of the Philippine Sea slab beneath SW Japan is shown by contours colored by depth. Basins are depicted as light-yellow regions. Regional faults in ocean and continent and seafloor spreading centers are shown as thick and thin black lines and thick red lines, respectively. Sky-blue lines represent present day coastlines. The locations of regional selected profiles $(\mathrm{a}-\mathrm{g})$ are indicated by the blue dashed lines. Arcs and relic arcs and ocean island basalt in the Philippine Sea plate are depicted as blue-purple areas and magenta polygons, respectively. The pink line represents the gravity gradient zone (Zheng et al., 2006). Drilling and paleomagnetic sampling sites: $1=$ IODP Site U1438; $2=$ DSDP 446; $3=$ ODP 1201; 4 = Luzon; 5 = DSDP 292; 6 = Saipan; $7=$ Izu-Bonin. EUR = Eurasian Plate; PSP = Philippine Sea Plate; $\mathrm{PAC}=$ Pacific plate; $\mathrm{IBM}=$ Izu-Bonin-Mariana Trench ST = Sagami Trough; $\mathrm{HB}=$ Huatung basin; $\mathrm{AS}=$ Amami-Sankaku basin; KD = Kita-Daito basin; $\mathrm{AP}=$ Amami Plateau; DR = Daito Ridge; ODR = Oki-Daito Rise; UP = Urdaneta Plateau; $\mathrm{BR}=$ Benham Rise.

The East Asia continental margin is located northwest of the TTT triple junction behind the northeast Japan arc and the Sagami Trough-Nankai Trough-Ryukyu Trench. Twisted arc hinges have developed along the continental margin in conjunction with marginal basins. The current Earth's surface topography configuration is marked by the wide rifted area of low elevations, which constitutes the first step occupying the continental margin of East Asia. However, how these features have evolved over time and what led to the formation of lowlands and marine inundation have remained unclear.

This article is protected by copyright. All rights reserved. 
The East Asia tectonics are characterized by an unusually large horizontal slab subducting into the mantle transition zone (Fukao et al., 1992; Huang and Zhao, 2006; Li et al., 2008; Miller and Kennett, 2006; Wei et al., 2012). The vertical profile across the Japan Trench shows continuous horizontal subduction of the Pacific slab, with the leading edge partially penetrating through the $660-\mathrm{km}$ discontinuity. South of the triple junction, the slab morphology beneath the IBM subduction zone remains horizontal within the mantle transition zone. A large volume of high-velocity anomalies lay beneath both the northern PSP and the East China Sea (ECS) shelf basin, with similar velocity magnitudes. Moreover, rather than a continuous sheet, internal segmentation inside the slab was recognized (Li et al., 2010; Tao et al., 2018). Numerical mantle flow models have been applied to explore the processes associated with horizontal slab formation (Zhong and Gurnis, 1995; Billen, 2010; Zhu and Shi, 2010; Čížková and Bina, 2015; Goes et al., 2017; Holt et al., 2018; Li et al., 2019). However, the ability to reproduce the explicit slab structure and evolution and reveal its characteristics and origin has remained elusive.

Here, we demonstrate recent efforts towards developing a deforming plate reconstruction for East Asia starting as components of rigid-plate global reconstructions (Zahirovic et al., 2016; Müller et al., 2016). Using new functionality (Gurnis et al., 2018), we have developed plate tectonic and deformation reconstruction for East Asia since 200 Ma using GPlates (www.gplates.org), in which the areas of plate deformation were nested within a global plate reconstruction dataset with self-consistency between plate motions, margin motions, plate geometries, and intraplate deformation (Liu et al., 2017; Gurnis et al., 2018; Müller et al., 2019). This new deforming plate reconstruction compares with the early models (e.g., Ma et al., 2019; Zahirovic et al., 2016) to test how the two contrasting plate reconstruction scenarios (deforming plate reconstruction versus rigid-plate reconstruction; TTT migration versus TTT stationary since $37 \mathrm{Ma}$ ) impact the geodynamic process of the plate and mantle system.

We address the plate-matle system evolution in East Asia with a series of forward mantle flow models constrained by evolving boundary conditions based on deforming plate reconstructions and dip variations in subducting slabs. Variations in the parameterization, such as alternative tectonic scenarios and mantle properties, aided in the exploration of the geodynamic evolution and evaluation of the physical factors that could have shaped the slab morphology in the mantle. The distinguishing present-day mantle structure beneath East Asia is reproduced while matching the residual (nonisostatic) topography. The good fit between modeling predictions and seismic images and residual topography documents how plate deformation and subducted plate architecture in the mantle record the timing, patterns, and processes of tectonics and how the coupled plate-mantle system (or Earth's surface-mantle system) evolves.

\section{Materials and Methods}

\subsection{New deforming plate reconstruction}

The global reconstruction dataset built by Müller et al. (2016) and Zahirovic et al. (2016) and regional reconstruction made by Liu et al. (2017) were modified with the platform GPlates (www.gplates.org); this platform uses a uniform time scale, deforming topologic polygon definitions, a hybrid absolute reference frame, and a global hierarchy of relative plate motion circuits to describe the geographic information of evolving plate boundaries and kinematic

This article is protected by copyright. All rights reserved. 
characteristics in one-million-year increments (Müller et al., 2016; Gurnis et al., 2018). Using the global reconstruction dataset, we implemented a tectonic and deforming reconstruction for the East Asian margin since 200 Ma nested with self-consistency among the plate motions, margin motions, plate geometries and intraplate deformation (Zahirovic et al., 2016; Liu et al., 2017; Gurnis et al., 2018; Ma et al., 2019). In the present plate framework, the Cenozoic history of the Pacific Plate is constrained through well-studied seafloor magnetic anomalies within the global plate circuit (Seton et al., 2012; Müller et al., 2016). We focused on the Cenozoic history of subduction along the Japan, Nankai, and Ryukyu Trenches and the PSP in East Asia (Texts S1 and S2 and Figure S1 in the supporting information). Based on geophysical and geological evidence from East Asia and the PSP, the reconstruction fully depicted the deforming plate kinematics and evolving plate boundaries. The model-predicted paleolatitudes around the PSP achieved a good fit with the published paleomagnetic results and the predictions of the other published models (Haston and Fuller, 1991; Wu et al., 2016; Ma et al., 2019). The development and death of small marginal basins were resolved based on oceanic crust and seafloor structure age data. The modified features were incorporated into time-evolving closed plate polygons in the global tectonic dataset, enabling the coverage of self-consistent surface kinematics over the region (Gurnis et al., 2012). Finally, a set of global seafloor age grids was generated according to the reconstructed plate kinematics (Zahirovic et al., 2016).

\subsection{Mantle Flow Models Assimilated with Reconstructed Tectonic History}

By solving the equations for conservation of mass, momentum, and energy in a spherical shell, global mantle convection in the Earth's interior was computed through geological time (Zhong et al., 2008). The kinematic history extracted from the tectonic reconstruction was imposed on the surface of the domain as velocity boundary conditions (Han and Gurnis, 1999). We developed a series of global models initiated at $200 \mathrm{Ma}$, with the reconstructed tectonic history assimilated into the flow (Text S3 and Table S1 in the supporting information and Table $1)$.

The new deforming plate reconstruction since 200 Ma was used for the Case 1 and Case 2 series. For Case 1, the slab assimilation from $176 \mathrm{Ma}$ to $90 \mathrm{Ma}$ was set to flat slab subduction by the method in Bower et al. (2015), and the slab assimilation during the other periods of time before $55 \mathrm{Ma}$ was set to subduction with a normal dip $\left(45^{\circ}\right)$. The flat subduction process was supported by the migration of Mesozoic magmatism, well-developed basement-involved thrust and broken foreland basin in the Yanshan Mountains (Liu et al., 2017; Liu et al., 2018; Wu et al., 2019). The Cenozoic subduction history and dip variation of Pacific and Philippine Sea slabs along the East Asian margin were specifically reconstructed (Text S4). After the arrival of the PSP to the north of Taiwan, we assumed that there was a stage in which subduction of the PSP replaced that of the Pacific Plate along the Ryukyu Trench-Nankai Trough during ca. 30 to 6 Ma. Because the subducting Pacific Plate in the Japan Trench and beneath proto-Ryukyu may have been one uniform slab over a long period even after the arrival of the PSP, a continuously evolving and smoothed but detached Pacific slab stencil (Figure S2) was created based on the method of Bower et al. (2015). For Case 2, the boundary conditions in the Cenozoic were identical to those in the Case 1 series, but the slab assimilation from $200 \mathrm{Ma}$ to $55 \mathrm{Ma}$ was set to normal dip $\left(45^{\circ}\right)$ subduction.

Case 3-1 and Cases 3-2 and 4-2 referred to from Ma et al. (2019) were set up with rigidplate reconstruction. All of the boundary conditions in Case 3-1 were collected from the

This article is protected by copyright. All rights reserved. 
reconstruction dataset of Zahirovic et al. (2016), and the slab assimilation from $200 \mathrm{Ma}$ to $0 \mathrm{Ma}$ was set to normal dip $\left(45^{\circ}\right)$ subduction. Case 3-2 and Case 4-2 are constrained with rigid-plate reconstruction but with different reconstructed tectonic histories, especially TTT triple junction migration histories, since $55 \mathrm{Ma}$. For slab assimilation from $55 \mathrm{Ma}$ to $0 \mathrm{Ma}$, Case 3-2 is set to normal dip $\left(45^{\circ}\right)$ subduction, and Case 4-2 is specifically set to variable dip subduction (Ma et al., 2019).

We started with a reference case (Case 1-1). Variations in the Clapeyron slope and viscosity layering were computed (Cases 1-2 to 1-6) with the same subduction boundary conditions as Case 1-1 (Table 1). We set Case 2-1 and Case 3-1 for comparison with Case 1-1 to test the effects of changing subduction dip angles and the deforming- or rigid-plate reconstruction constraints. Comparison among Case 4-2, Case 3-2, and Case 1-2 with the same viscosity layering and Clapeyron slope is also significant to test the effects with or without the detailed creation of Pacific slab stencil from $30 \mathrm{Ma}$ to $6 \mathrm{Ma}$, different TTT triple junction migration processes (Ma et al., 2019), and the rigid-plate reconstruction or the deforming plate reconstruction.

Table 1. Case-specific parameters

\begin{tabular}{lllll}
\hline Case $^{4}$ & $\begin{array}{l}\text { Viscosity } \\
\text { prefactor }\left(\eta_{0}(r)\right)^{1}\end{array}$ & $\begin{array}{l}\text { Deforming } \\
\text { plate } \\
\text { reconstruction }\end{array}$ & $\begin{array}{l}\text { Clapeyron } \\
\text { slope }(\gamma) \\
\left(\mathrm{MPa} \cdot \mathrm{K}^{-1}\right)\end{array}$ & $\begin{array}{l}\text { Slab } \\
\text { assimilation } \\
\text { before } 55 \mathrm{Ma}^{3}\end{array}$ \\
\hline Case 1-1 & $1,0.2,1,30$ & $\mathrm{~L}$ & -1.5 & Flat slab \\
Case 1-2 & $1,0.2,1,50$ & $\mathrm{~L}$ & -1.5 & Flat slab \\
Case 1-3 & $1,0.2,1,50$ & $\mathrm{~L}$ & -3.0 & Flat slab \\
Case 1-4 & $1,1,1,50$ & $\mathrm{~L}$ & -1.5 & Flat slab \\
Case 1-5 & $1,0.2,1,30$ & $\mathrm{~L}$ & -3.0 & Flat slab \\
Case 1-6 & $1,1,1,30$ & $\mathrm{~L}$ & -1.5 & Flat slab \\
Case 2-1 & $1,0.2,1,30$ & $\mathrm{~L}$ & -1.5 & Normal dip \\
Case 3-1 & $1,0.2,1,30$ & $\mathrm{Z}$ & -1.5 & Normal dip \\
Case 3-2 & $1,0.2,1,50$ & $\mathrm{Z}$ & -1.5 & Normal dip \\
Case 4-2 & $1,0.2,1,50$ & $\mathrm{M}$ & -1.5 & Normal dip \\
\hline
\end{tabular}

Note. 1 Four values of the prefactor are successively used for the mantle above $150 \mathrm{~km}$, between $150 \mathrm{~km}$ and $410 \mathrm{~km}$, between $410 \mathrm{~km}$ and $660 \mathrm{~km}$, and below $660 \mathrm{~km}$.

$2 \mathrm{~L}, \mathrm{Z}$, and $\mathrm{M}$ indicate the cases based on our new deforming plate reconstruction, on Zahirovic et al.'s (2016) plate reconstruction, and on Ma et al.'s (2019) plate reconstruction, respectively. Z and $\mathrm{M}$ are without deforming reconstruction.

This article is protected by copyright. All rights reserved. 
3 Mantle flow modeling starts at $200 \mathrm{Ma}$. For slab assimilation before $55 \mathrm{Ma}$, we set flat slab subduction from $176 \mathrm{Ma}$ to $90 \mathrm{Ma}$ and normal dip $\left(45^{\circ}\right)$ subduction before $176 \mathrm{Ma}$ and after 90 Ma or normal dip $\left(45^{\circ}\right)$ subduction from $200 \mathrm{Ma}$ to $55 \mathrm{Ma}$.

4 Case 3-2 and Case 4-2 are cited from Ma et al. (2019) and are renamed here.

\subsection{Modeling of dynamic topography}

Mantle convection and mantle viscous drag caused by a sinking slab deflect the lithosphere and generate topography at the surface, referred to as dynamic topography (Flament et al., 2013). There were two means of estimating this topography. The mantle flow-induced dynamic topography (Liu and Nummedal, 2004) and its evolution were calculated by using the mantle flow model described above and the methods described by Yang et al. (2016). The surface dynamic topography was computed with the density from the composition and thermal fields below $350 \mathrm{~km}$ depth. Alternatively, the residual topography was calculated by subtracting the isostatic topography induced by crustal and lithospheric thickness and density variations from the total topography (Liu and Nummedal, 2004; Liu et al., 2011; Flament et al., 2013; Faccennaa et al., 2014; Hoggard et al., 2017; Text S5 and Figure S3 in the supporting information). The dynamic topography computed by the mantle flow model should fit the residual (observed) topography of the present day and that found during their evolution. Furthermore, this topography was used to evaluate the mantle flow models formulated in East Asia.

\section{Results}

\subsection{Reconstructed plate tectonics and deformation history}

Following the Jurassic and Cretaceous subduction of the Izanagi plate, in the reconstruction, the Izanagi-Pacific mid-ocean ridge initiated subduction beneath and subparallel to the East Asian margin at approximately $55 \mathrm{Ma}$ (Müller et al., 2016; Figure 2). At ca. $50 \mathrm{Ma}$, the PSP was located near the equator as a back-arc, overriding the southward-subducting Pacific plate. It then continuously moved northwards, and reached a rate of approximately $8 \mathrm{~cm} / \mathrm{yr} \mathrm{ca} .34$ Ma. During the period of 55-50 Ma, slab rollback induced a N-S-trending extensional force pulling the Amami Plateau away from the Daito Ridge and creating small intervening basins with new oceanic crust. The initiation of IBM subduction at approximately $52 \mathrm{Ma}$ (Reagan et al., 2019) could have resulted from large plate age and density contrasts within the Philippine relic arc (Leng and Gurnis, 2015). Synchronously, short-lived hotspots and mantle upwelling were present beneath the Kita-Daito basin, which subsequently triggered propagating rifts in the basin and excessive basalts in the ocean islands of the Benham Rise, Oki-Daito Rise, and Urdaneta Plateau as the PSP drifted and rotated. To the southeast of the Eurasian Plate, the proto-South China Sea (SCS) opened at a rate of 4-8 cm/yr (Figure 2, A-C). Between $55 \mathrm{Ma}$ and $34 \mathrm{Ma}$, the Pacific Plate converged with the Eurasian Plate at approximately $6 \mathrm{~cm} / \mathrm{yr}$. The western part of the ECS was stretched in a SE or SSE orientation from 60 to $40 \mathrm{Ma}$. Responding to a counterclockwise change in the subduction orientation of the Pacific Plate starting in the northwest motion ca. $50 \mathrm{Ma}$ into the southwest in the early Oligocene, the principal direction of extension in the Bohai Bay basin changed from SE during 66-42 Ma to SSE after $42 \mathrm{Ma}$ and continued to rotate clockwise to the south after 34 Ma (Figure 2, A-F, Figure S4).

This article is protected by copyright. All rights reserved. 

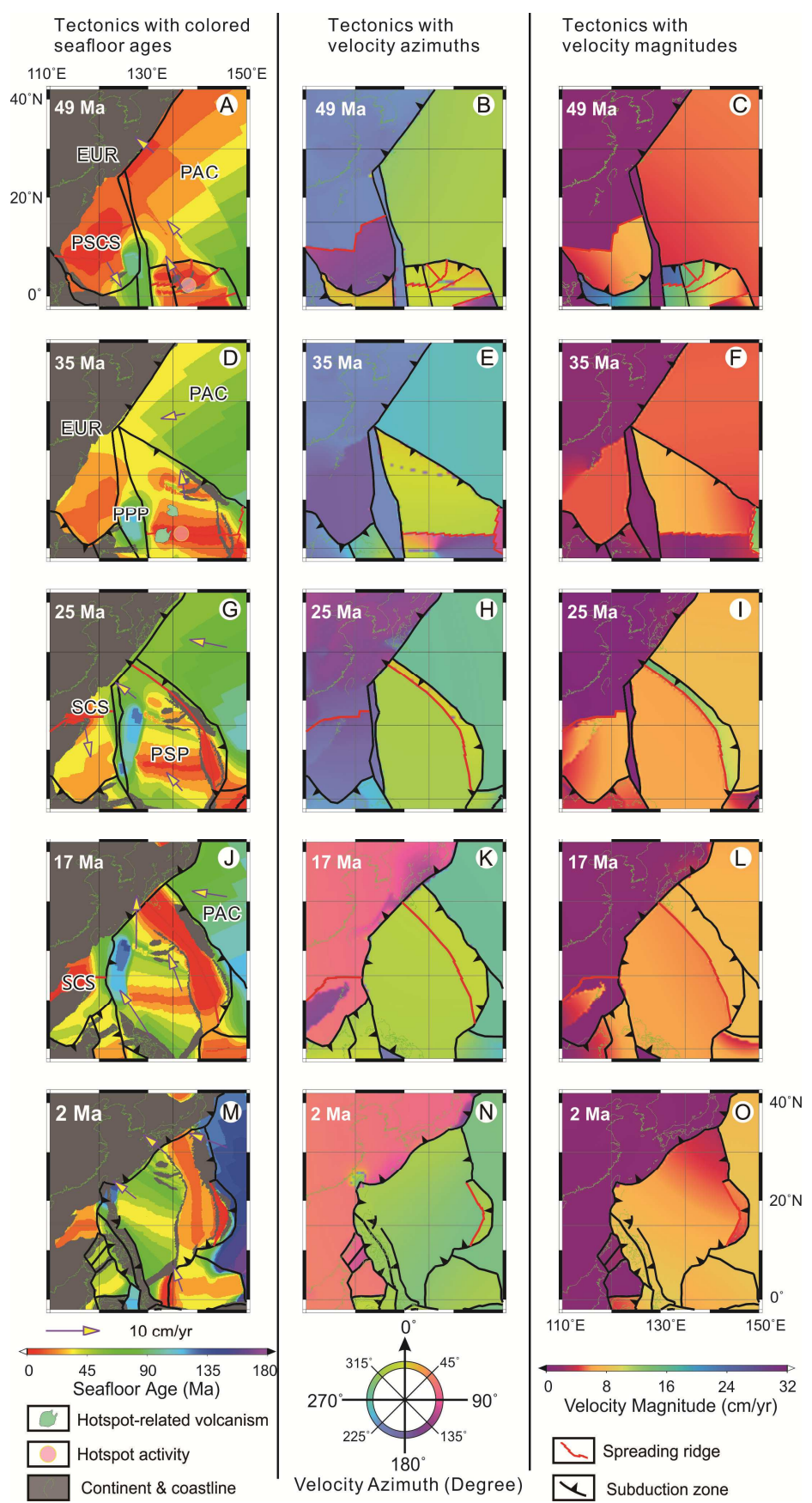

Figure 2. Reconstructed tectonic and coupled plate motion history of East Asia at $49 \mathrm{Ma}, 35 \mathrm{Ma}$, $25 \mathrm{Ma}, 17 \mathrm{Ma}, 10 \mathrm{Ma}$ and $2 \mathrm{Ma}$ in the absolute reference system. The subfigures in the left column show the tectonics with colored seafloor ages, and the subfigures in the middle and right columns show the corresponding velocity azimuths and magnitudes over the region, respectively. $\mathrm{PPP}=$ Proto-Philippine Sea plate, $\mathrm{PSCS}=$ Proto-South China Sea. The other symbols are the same as those in Figure 1.

This article is protected by copyright. All rights reserved. 
In the early Oligocene, Pacific Plate motion changed to the southwest. At ca. $32 \mathrm{Ma}$, the extensional velocity greatly decreased in the East Asian margin, and the southeastward extension in the ECS shifted eastwards (Figure S4). The seafloor spreading in the proto-SCS basin and the West Philippine basin ceased. The PSP continued to move northward at approximately $6 \mathrm{~cm} / \mathrm{yr}$, with a propagating rift in the central basin spreading center of the west Philippine basin. At ca. $32 \mathrm{Ma}$, the South China Sea (SCS) spreading began up, which might be driven by the proto-SCS slab pull as its southeast-dipping subduction. After ca. $30 \mathrm{Ma}$, the breakup of the proto-IBM arc induced rifting of the Shikoku and Parece-Vela basins (Figure 2, G-I).

Oblique convergence between the PSP and Eurasia may have started between the late Oligocene and the early Miocene, and subduction of the PSP beneath East Asia propogated diachronously along the Ryukyu Trench. At ca. $25 \mathrm{Ma}$, the Eurasian Plate moved southward. At the southernmost end of the continent, the SCS basin opened at a rate of $8 \mathrm{~cm} / \mathrm{yr}$ and extended in an SSE orientation (Figure S4). In the Shikoku Basin, the local plate motion reached approximately $14 \mathrm{~cm} / \mathrm{yr}$ due to seafloor spreading. The westward convergence of the Pacific Plate increased to approximately $10 \mathrm{~cm} / \mathrm{yr}$, which persisted until the present. On the western boundary of the PSP, east-dipping subduction of the SCS basin along the Manila Trench initiated ca. $20 \mathrm{Ma}$ (Yumul et al., 2003) (Figure 2, G-L).

During the early Miocene, the opening and rapid extension of the Japan Sea basin and the associated rotation of the Japanese arcs resulted from ongoing rollback of the Pacific slab, southward extrusion of the NE Japan arc, and northward convergence of the PSP (Figure 2, J L). During this stage, the motion of the Eurasian Plate shifted eastward. At the end of the middle Miocene, crustal extension in the Japan Sea basin was completely replaced by contractional tectonics (Figure S4).

The motion of the PSP may have been dominated by rotation during the late Miocene. Since ca. $5 \mathrm{Ma}$, PSP subduction under the East Asian margin resumed. The northern and central Okinawa Trough attained its most extensive rifting during the Pliocene. In the southern part of the Ryukyu arc, the late Miocene oblique intrusion of the Luzon arc into the southern China passive margin led to the subduction of the East Asian continent beneath the PSP and the formation of the Taiwan orogeny (Figure 2, M-O; Figure S4).

\subsection{Mantle flow modeling}

With the constraints of velocity boundary conditions extracted from the tectonic reconstruction, a series of global flow models were set up (Cases 1-1 to 1-6, Case 2-1, and Case 3-1) with different tectonic reconstructions and different parameter settings (Table 1; Text S3; Table S1). Our Cases 1-1 to 1-6 and Case 2-1 with deforming plate reconstruction are contrasted with Case 3-1 and Cases 3-2 and 4-2 (Ma et al., 2019) with rigid-plate reconstruction. We evaluated the flow models through a comparison of their predicted present-day structures to high-resolution P-wave seismic tomography models (MIT-P08 (Li et al., 2008), GAP-P4 (Fukao and Obayashi 2013), and FWEA18-P (Tao et al., 2018)) along four E-W and three SW-SE profiles across East Asia (Figure 3; Figure S5; Text S6; Figure S9). The predicted slab structures in the Case 1 series generally agreed with the tomographic images with a relatively high accuracy from $72 \%$ to $77 \%$ for MIT-P08 and from $87 \%$ to $92 \%$ for GAP-P4 (Table S2A). Several major features were reproduced in Case 1-1, including the expansive mantle wedge beneath East Asia, the horizontal Pacific slab with its leading edge extending into the uppermost lower mantle, internal segmentation of the slab within the mantle transition zone, and a pile of

This article is protected by copyright. All rights reserved. 
Mesozoic slabs in the lower mantle under Qinling, Ordos Basin, and South China, with the highest accuracy (Table S2A). The predicted slab structure in Case 1-1 shows a good match with the horizontal structure of the slab in profile A (Figure 3A; Figure S5A). The slab in the transition zone extends from beneath the Japan Sea basin to the Bohai Bay basin, and the leading edge deflects downward into the lower mantle with a $30^{\circ}$ dip. We obtained better agreement with the tomographic model MIT-P08 in terms of horizontal Pacific slab penetration.

Along profile B below Kyushu, the predicted segmented slab may correspond to the apparent narrowing high-velocity anomaly in the seismic images of GAP-P4 and MIT-P08 (Figure 3B; Figure S5B). The west-dipping PSP at shallow depths rests above the necked segments. The predicted Pacific slab subducted along the IBM Trench is shorter than indicated by tomographic images in profile $\mathrm{C}$ (Figure 3C; Figure S5C). Case 1-1 also predicted the gradual disappearance of stagnant slabs beneath South China, which could have been derived from the cession of subduction along the southern Ryukyu arc before the Luzon-Eurasia collision (Figure $3 \mathrm{C}, \mathrm{D})$. The reference case reproduces the approximate segmented subslabs, including subslab-1 beneath the PSP, subslab-2 beneath the ECS (the shallow flat tip in profile C), subslab-2A beneath the Yellow Sea and ECS.

By changing the character of subduction before $55 \mathrm{Ma}$ (so that the slab has a normal dip $\left(45^{\circ}\right)$ as opposed to flat), we find that the slab structure within the mantle transition zone is hardly changed (Case 2-1 versus 1-1). A comparison of both predicted current architectures in the lower mantle with those in seismic tomography (GAP-P4 and MIT-P08) reveals that Case 11 has a better fit and higher accuracy than Case 2-1 for MIT-P08 and GAP-P4 (Table S2A). Furthermore, Cases 3-1 and 3-2 agree poorly with seismic images with lower predicted accuracies (Table S2A), in which subduction and northward migration of the PSP through the Ryukyu Trench initiated ca. $47 \mathrm{Ma}$, and the TTT junction has been fixed at the present-day location since ca. $37 \mathrm{Ma}$ (Figure 3; Figure S5). The slab penetrating into the lower mantle resulted from long-term anchoring of IBM subduction. A substantial near vertical slab in profile A, east of the clear seismicity zone (Figure 3A), was caused by the ephemeral northeastward migration of the TTT triple junction beside northeastern Honshu at $7 \mathrm{Ma}$. The differences between the outcomes of Cases 1-1 and 3-1 indicate that the TTT triple junction should have retreated along the East Asian margin after $35 \mathrm{Ma}$ rather than before it (Ma et al., 2019).

Moderate changes in the radial mantle viscosity (Cases 1-2, 1-4, and 1-6) and Clapeyron slope at $660 \mathrm{~km}$ depth (Cases 1-3, 1-5) have no substantial influence on the general slab morphology within the upper mantle (Figure 4) and predicted accuracies (Table S2A). Specifically, an increase in the viscosity jump between the mantle transition zone and the lower mantle to 50 (Case 1-2) restrained the sinking of the Izanagi slab and westward penetration of the flat slabs in the lower mantle transition zone (Ma et al., 2019). Finally, the absence of the lowerviscosity asthenosphere above the mantle transition zone resulted in a 3-degree westward lateral shift of the Izanagi slab in the lower mantle (Cases 1-4, 1-6). The Pacific slab shows weaker penetration through the 660-km discontinuity (Cases 1-4, 1-6). Despite differences in detail, there is a general fit among the predicted slab structures with the seismic images.

This article is protected by copyright. All rights reserved. 

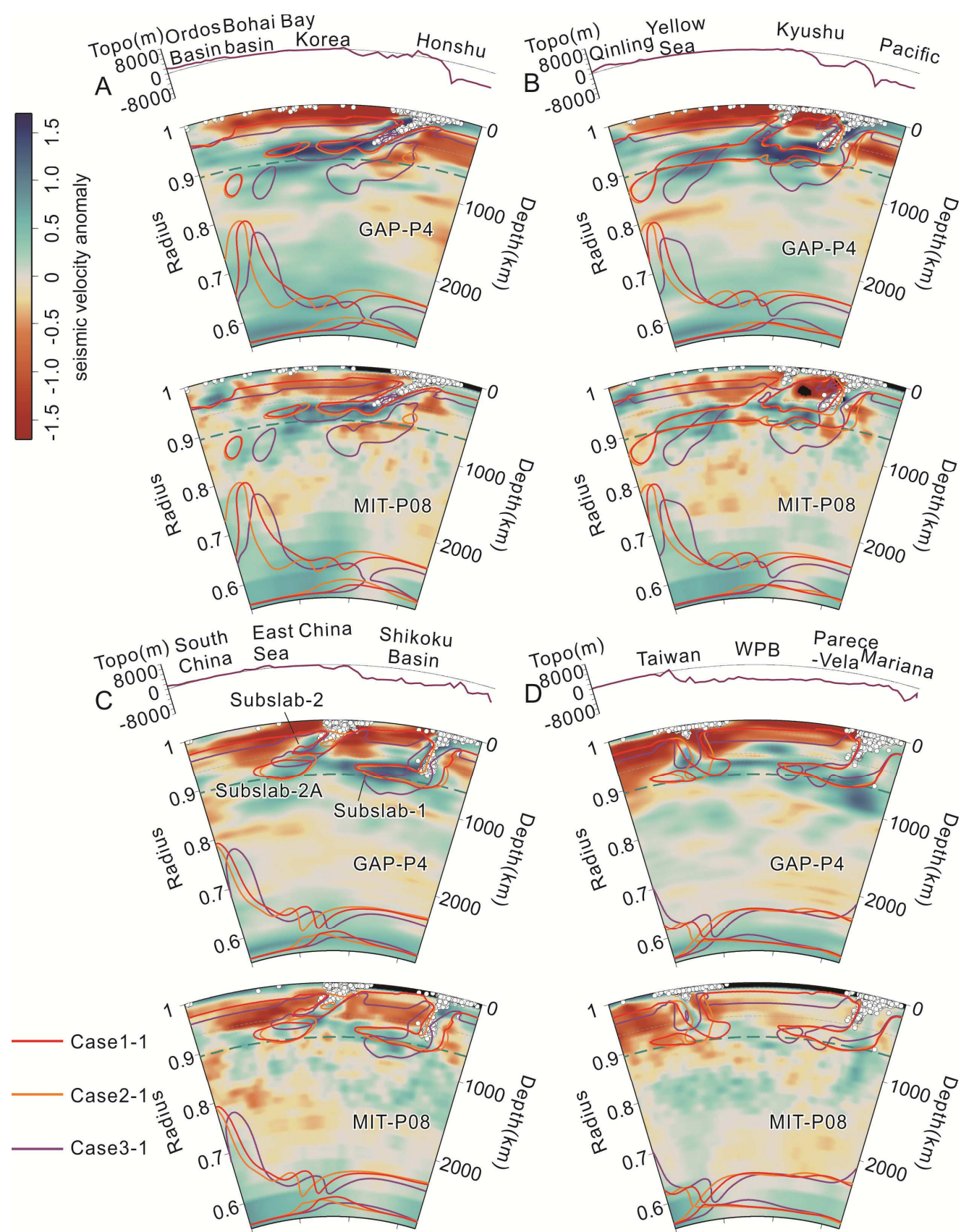

Figure 3. Comparison of predicted slab structures with seismic tomography. The slab contours delineating mantle 0.9 times the ambient temperature for Cases 1-1, 2-1, and 3-1 are compared with vertical slices of $P$-wave tomographic models MIT-P08 and GAP-P4 along profiles (A) to (D) shown in Figure 1. Small, white circles show the seismicity from 1 January 2010 to 19 February 2017 within $100 \mathrm{~km}$ of the profile (Ma et al., 2019). The topography is shown at the top of the profile. WPB = West Philippine basin. The other symbols are the same as those in Figure 1.

This article is protected by copyright. All rights reserved. 


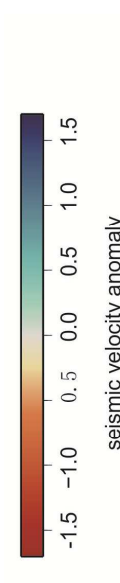

Topo (m) Ordos Bohai Bay Korea Topol Basin basin

A 0000
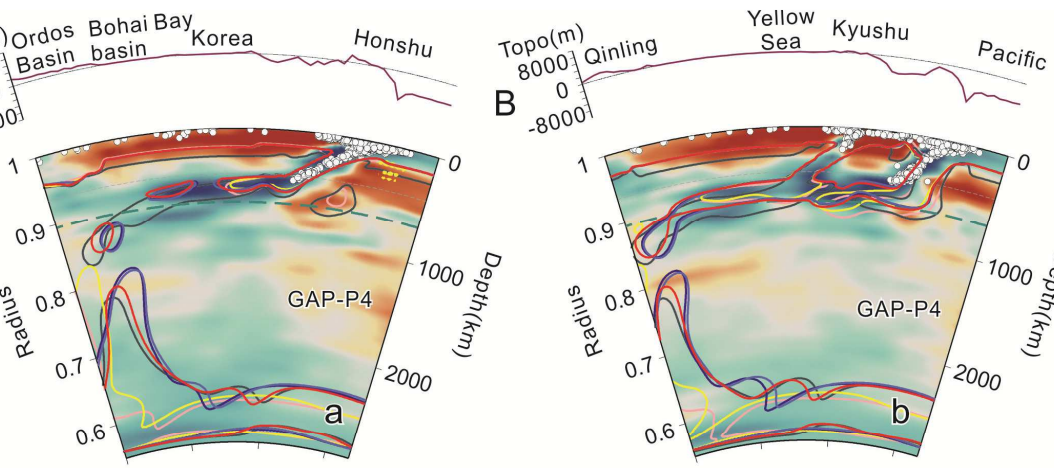

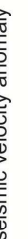

है

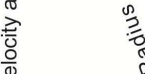
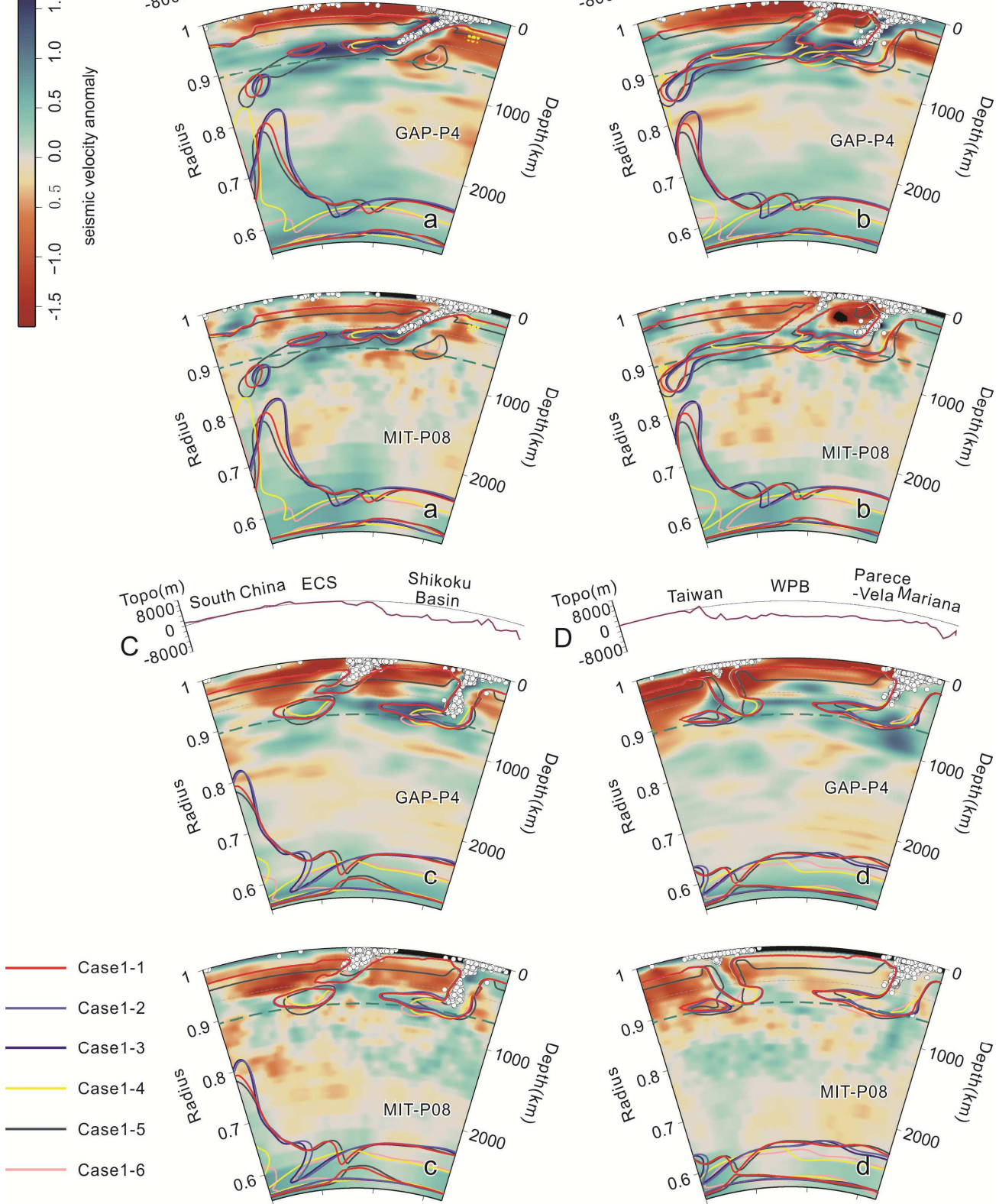

Figure 4. The slab structures predicted by Case 1-1, Case 1-2, Case 1-3, Case 1-4, Case 1-5, and Case 1-6 are compared with vertical slices of $P$-wave tomographic models MITP-08 and GAPP4 along profiles (A) to (D). The symbols are the same as those in Figures 1 and 2. The locations of the profiles are shown in Figure 1.

A comparison of predicted current mantle structures from Cases 1-2 and 4-2 (both with the same lower mantle viscosity, 50; Figure S6) with seismic tomography reveals that Case 1-2 better fits tomography than Case 4-2. Although the predicted accuracies from Case 1-2 for the

This article is protected by copyright. All rights reserved. 
mantle are marginally less than those from Case 4-2, the accuracies from Case 1-2 for the Pacific Plate and Izanagi Plate separately are mostly higher than those from Case 4-2, except one for the predicted Izanagi Plate in model GAP-P4 (Table S2). The predicted horizontal slab within the mantle transition zone and lower mantle slab in Case 1-2 extends further landwards and shallower than those predicted by Case 4-2 because Eurasian plate deformation reconstruction changes the locations of subduction zones. If we compare the predictions made by Case 1-1 (the lower mantle viscosity 30) and Case 4-2, we find differences in westward shifting of the predicted slabs, and Case 1-1 provides a better fit and higher accuracies (Table S2) in the sections of Supplementary Figure S6. As more extensional deformation occurred since Cretaceous time, the subduction zones were located more westward, and the trenches retreated a greater distance compared with the rigid-plate reconstruction model. The migration of the subduction zones induced by plate deformation impacts the predicted mantle architecture.

Overall, the slab structures predicted by Case 1-1 are in good agreement with the tomographic images of models MITP-08 and GAP-P4 and even the high-resolution regional model FWEA18 (Tao et al., 2018), with the highest model-predicted accuracies for MIT-P08 and GAP-P4 (Table S2A). These results imply that reasonable deforming plate reconstruction and detailed slab assimilation are the main constraints and controls in four-dimensional geodynamic modeling.

3.3 Predicted dynamic topography and comparison against present-day residual topography

Mantle flow drives the dynamic topography of the Earth's surface (Liu and Nummedal, 2004; Liu et al., 2011; Flament et al., 2013; Faccennaa et al., 2014). Dynamic topography was computed for the flow models along the East Asian margin, with similar amplitudes from approximately $-800 \mathrm{~m}$ to $200 \mathrm{~m}$ (Figure 5). The highly dynamic subsidence centers in the Case 1 and Case 2 series are distributed along the back-arc regions of the Manila, Ryukyu, Japan, and IBM subduction zones, and the subducting Pacific Plate in front of the Japan and IBM Trenches appears to be a dynamic topographic high. Behind the margins, a wide dynamic topographical low of approximately -650 to -400 m occurs along the coastal area of South China. Case 3-1, with a different plate reconstruction for East Asia during the Cenozoic, generated a broad dynamic topographic low behind the Ryukyu Trench but predicted a similar level of dynamic topography as Case 1-1 using an identical radial viscosity. Increasing the viscosity of the lower mantle in Cases 1-2 and 1-4 resulted in slightly higher amplitudes of the dynamic topographic low than in Cases 1-1. This was caused by the slower descent of slabs through the lower mantle, as increasing the viscosity of the lower mantle with an invariant distribution of slabs leads to lower amplitudes (Hager, 1984). With the same viscosity layering as in Case 1-1, Case 1-5, with a lower Clapeyron slope, generated a similar amplitude of dynamic topography. Unlike Case 1-2, Case 1-4 featured an absence of low-viscosity asthenosphere above the mantle transition zone, which increased the flux of material into the lower mantle, lowering the amplitude of the dynamic topographic low. Moreover, we also found that Case 2-1 predicted nearly the same amplitude of dynamic topography as Case 1-1. Therefore, the dip of plate subduction before 55 Ma does not strongly influence the present-day dynamic topography.

This article is protected by copyright. All rights reserved. 

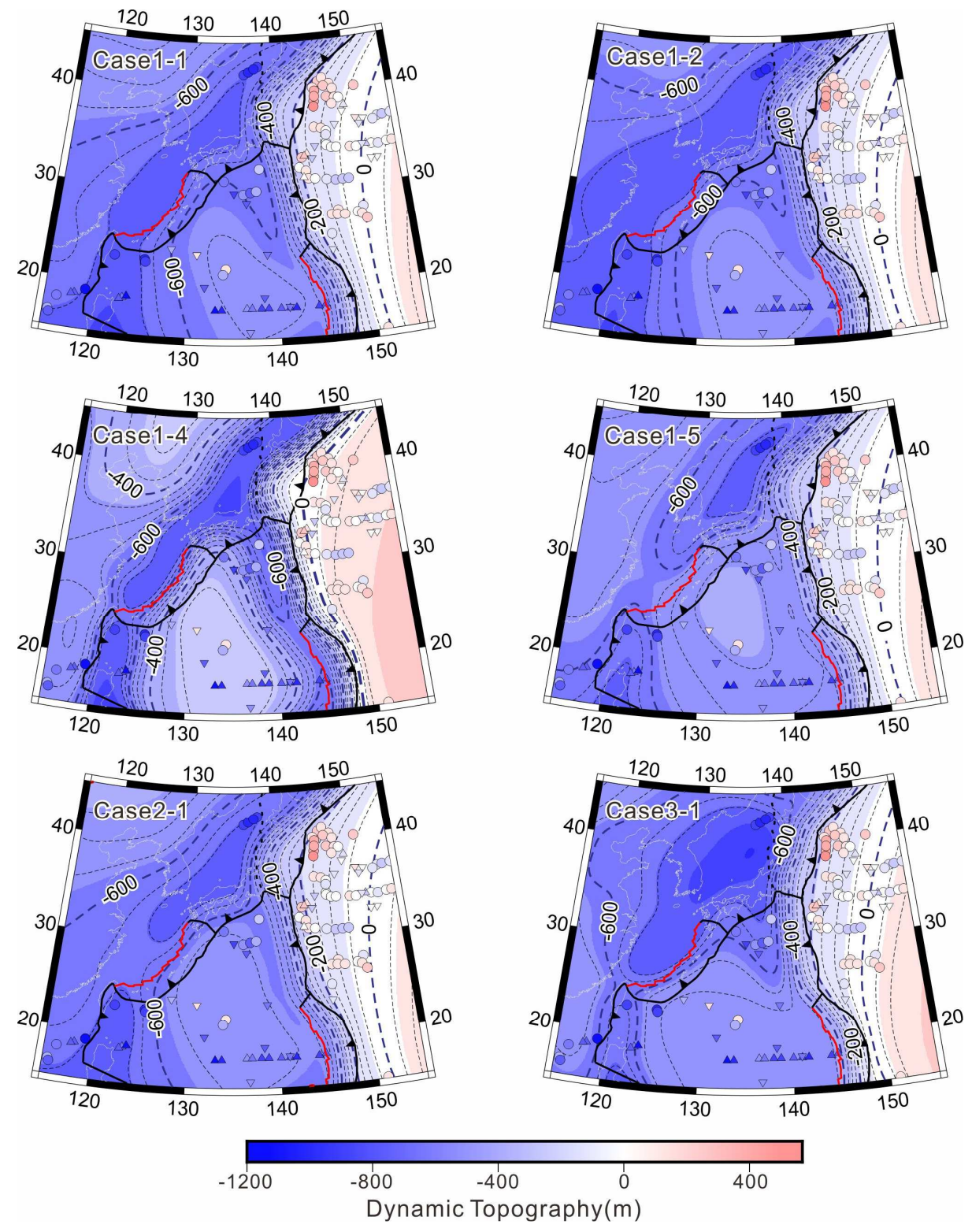

Figure 5. The predicted dynamic topography of the mantle flow models of Cases 1-1, 1-2, 1-4, $1-5,2-1$, and 3-1 is compared with the observed residual topography in the western Pacific, Philippine Sea, Japan Sea, and South China Sea (Hoggard et al., 2017). High-accuracy residual topography observations are shown by solid circles. The lower limit for residual depth is given by upward pointing triangles; the upper limit for residual depth is given by downward pointing triangles.

We compared these predicted dynamic topographies against residual topographies generated by removing isostatic and thermal cooling of the oceanic lithosphere (Hoggard et al., 2017). Root-mean-square (RMS) comparison of the predicted present-day dynamic topography with residual topography values in the western Pacific shows RMS differences of 260-300 m (Figure 6). The match between dynamic and residual topography is comparatively better for Case

This article is protected by copyright. All rights reserved. 
1-1 than the other cases, with an RMS value of $260 \mathrm{~m}$. The tracking of dynamic topography with time is often more informative to the changing dynamic conditions regionally (Figure S7). Here, we track the changing topography with residual topographies computed from onshore and offshore boreholes through sedimentary sections and calculate the postrift residual subsidence that exceeds the theoretical thermal subsidence (Text S5). The baseline dynamic topography from this method is unknown, and only the changes with time can be inferred. A cross-section through Japan and Korea and into China is particularly informative (Figure 7, cross-section b). In the residual topography over the Cenozoic, we infer only mild fluctuations of approximately \pm $200 \mathrm{~m}$, except for two trends that are evident in multiple bole holes. The first is an uplift and subsidence event of less than approximately 400 meters between 50 and $40 \mathrm{Ma}$ (Figure S7), and the other is a gradual subsidence of a few hundred meters since approximately 20-15 Ma, which is seen regionally through East Asia. In general, these trends are consistent with the models shown here, especially for Case 1-1, which reproduces those cycles of uplift and subsidence. Earlier subsidence at approximately 65-60 Ma occurred in response to the descent of the Izanagi slab through the $660 \mathrm{~km}$ discontinuity (Figure 7; Figure S7). However, in general, the changing topography above the slab has been subdued, as the slab has been partially supported by the phase transition at $660 \mathrm{~km}$ between Ringwoodite and Bridgemanite, which has a negative Clapeyron slope. Interestingly, some models are starting to show slow subsidence over the last 10 or $5 \mathrm{My}$, such as Case 1-1, which could be reflective of the slow descent of slabs into the lower mantle. This subsidence was recorded by the residual topographic curves differentiated from multiple boreholes in the Bohai Bay basin (Figure S7E).

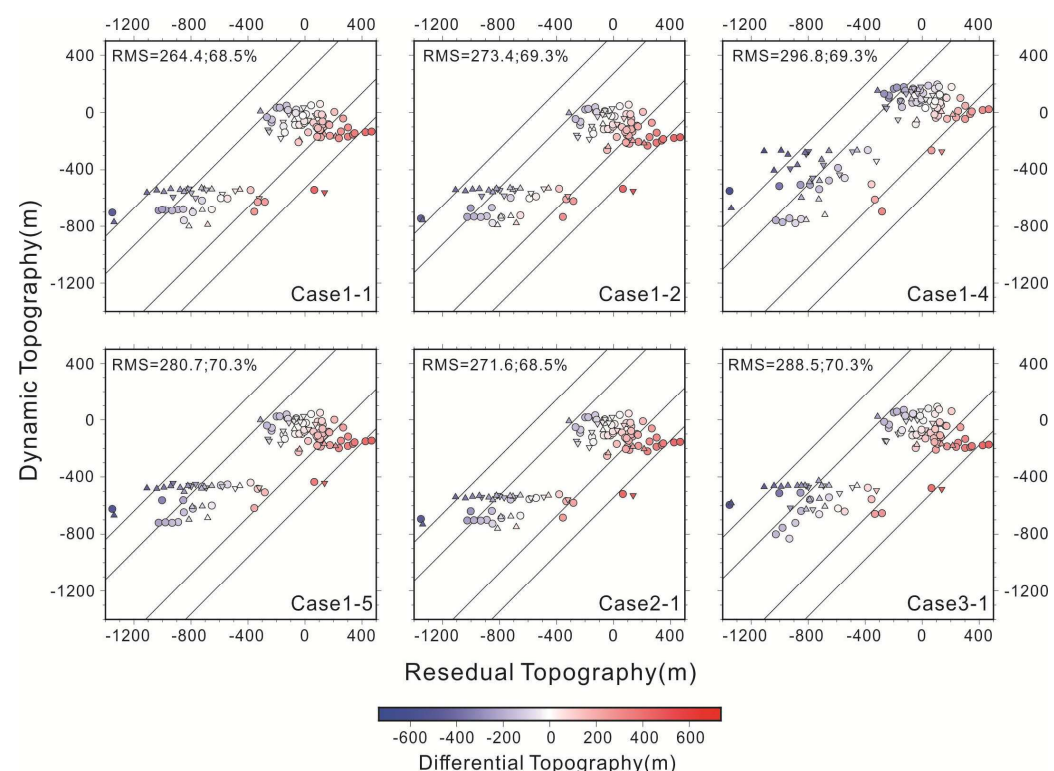

Figure 6. The root-mean-square (RMS) analysis of present-day dynamic topography predicted by models of Cases 1-1, 1-2, 1-4, 1-5, 2-1, and 3-1 and observed residual topography. Circles and triangles represent 111 projection points of residual topography observations in the ocean from Hoggard et al. (2017) versus the predicted present-day dynamic topography, respectively. The color filled in the circles and triangles represents the difference between the predicted dynamic topography and residual topography.

This article is protected by copyright. All rights reserved. 


\section{Discussion}

The geodynamics of the East Asian margin are of considerable interest, and the processes have been explored in recent papers, including Wu et al. (2016), Faccenna et al. (2018), Ma et al. (2019), and Yang et al. (2019). Wu et al. (2016) proposed a set of tectonic reconstruction schemas of East Asia since $52 \mathrm{Ma}$ and the corresponding trench subduction history based on backward unfolding of interpreted subducted slabs onto the surface. They proposed the concept of an "East Asian Ocean", which was gradually replaced by the growth of the PSP core. With ambiguous kinematics of the proposed "East Asia Ocean", we were unable to test the model with a forward geodynamic approach. The restoration (Wu et al., 2016) generally agrees with a "trench retreat" pattern since $30 \mathrm{Ma}$, with a TTT triple junction shift since ca. $16 \mathrm{Ma}$, but it is difficult to reasonably explain the observed detachment of the subducted Pacific slab along the Proto-Ryukyu Trench resulting from oblique subduction of the PSP slab beneath Eurasia (Asamori and Zhao, 2015). In contrast, Faccenna et al. (2018) noted the northeastward movement of the TTT triple junction since ca. $20 \mathrm{Ma}$ and argued that the subducted PSP was detached at 10-12 Ma along their reconstructed E-W profile at $28^{\circ} \mathrm{N}$. In fact, this model did not reveal the replacement of Pacific plate subduction by PSP subduction along the Proto-Ryukyu from their profile reconstruction and modeling. Using rigid-plate tectonic reconstruction, Ma et al. (2019) presented an initial set of forward mantle-flow models that matched the main features in the seismic tomography below the East Asian margin and predicted the detachment of the Pacific slab below the Nankai Trough since $6 \mathrm{Ma}$. However, the model was also unable to reproduce the complicated relationship between the PSP and Pacific plate spatially and temporarily beneath Proto-Ryukyu.

This article is protected by copyright. All rights reserved. 

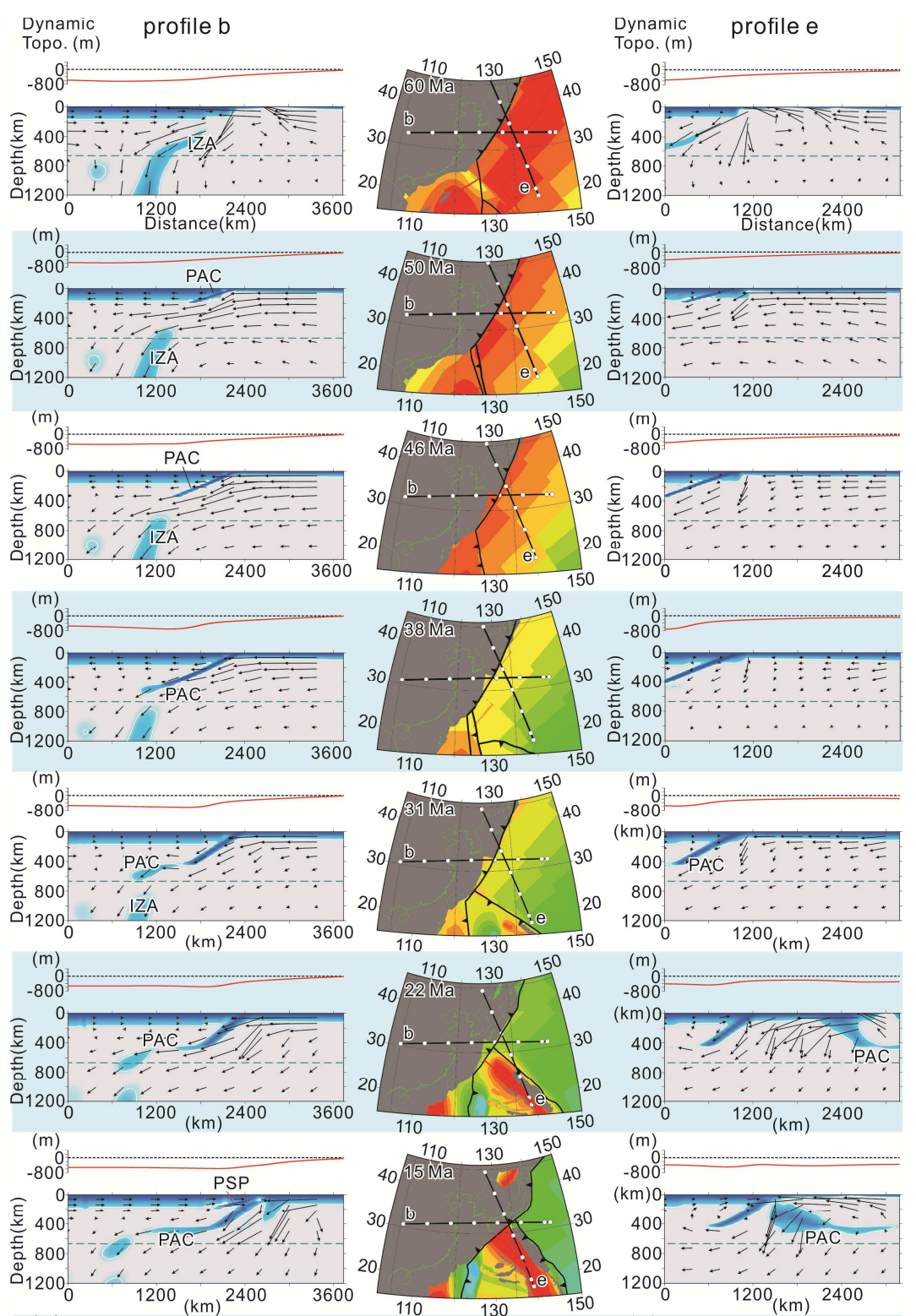

1200
(m)
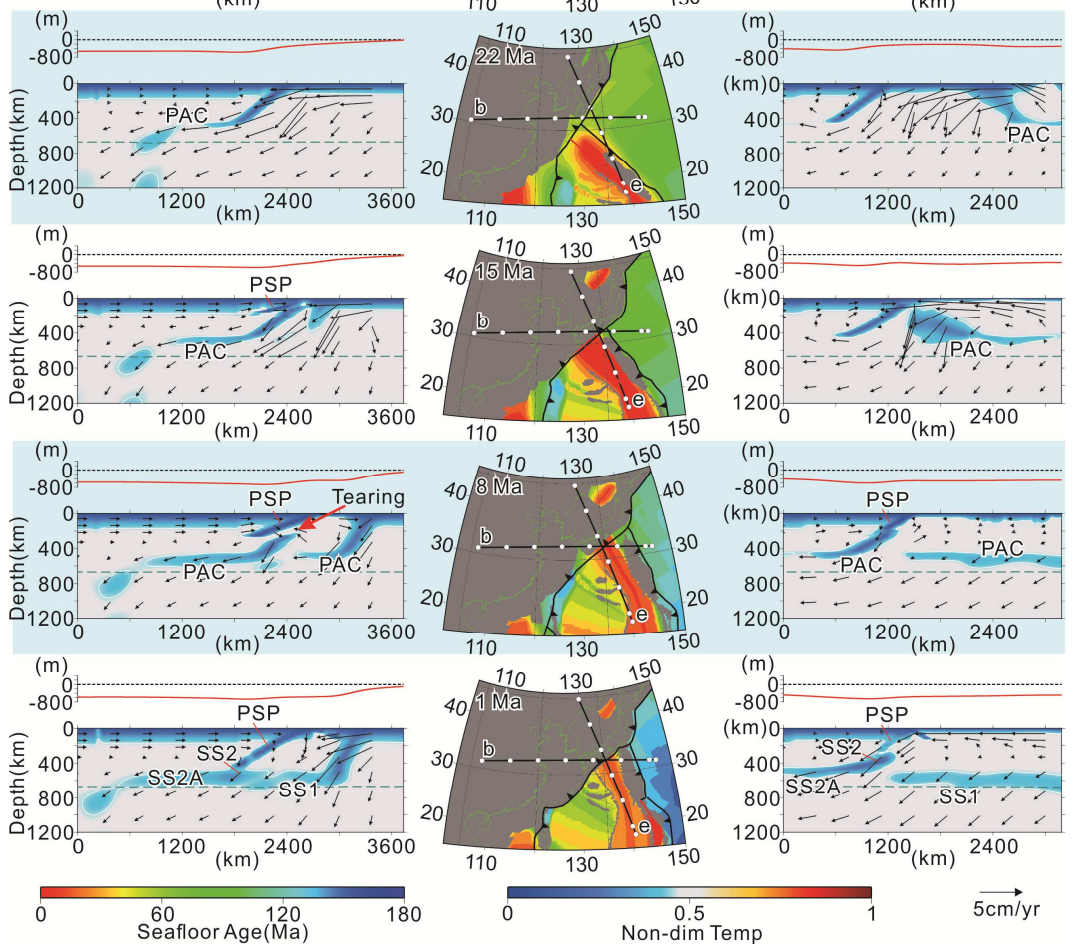

Figure 7. Evolution of slab subduction. Slab horizontal subduction and slab segmentation modeled by Case 1-1 are shown in vertical profiles b (left column) and e (right column) and map

This article is protected by copyright. All rights reserved. 
view (middle column) for mutual identification. The horizontal dashed line is the phase transition at $660 \mathrm{~km}$ depth. For each profile, slabs are represented as a blue color delineated by a nondimensional temperature of $<0.45$, and mantle flow velocities are shown with black vectors. IZA = Izanagi plate; SS1=subslab-1; SS2=subslab-2; SS2A=subslab-2A. The other symbols are the same as those in Figure 1. The present-day location for profiles $b$ and e is shown in Figure 1.

The good fits between the flow model predictions and seismic images and residual topography provide a capacity to interpret the 4-D geodynamics of plate-mantle systems in East Asia. The successful prediction of the present-day mantle structure by Case 1-1 specifically, or more generally by the Case 1 series, implies that the time-dependent forward mantle flow model combined with the reconstructed tectonic history and subducting slab geometry (Text S4) could clarify the space-time process of horizontal subduction in the transition zone in deep time (Fig. 6; Figure S8). From ca. 50 to $30 \mathrm{Ma}$, the Pacific slab was subducted beneath the East Asian margin, with an increasing subduction angle from nearly flat to $45^{\circ}$. Since ca. $30 \mathrm{Ma}$, the PSP rotated clockwise, and the triple junction migrated northeastward along the East Asian margin. Under this tectonic process, Pacific Plate subduction was replaced with PSP subduction beneath the Ryukyu Trench, and a series of deep structures were produced. A subvertical tear formed at the triple junction and divided the Pacific slab into one slab subducting along the Japan Trench and another subducting along the IBM Trench. A subhorizontal tear that propagated along the Ryukyu Trench and Nankai Trough in the late Miocene induced the detachment of the Pacific slab and torn Pacific slab sinking, leaving a gap between the Pacific and initially gently dipping subducted PSP (Wortel et al., 2009; Figure 8A).

After ca. $6 \mathrm{Ma}$, the Pacific slab was finally completely detached, and the horizontal slab in the transition zone became segmented (Figure 7; Figure S8). The detached slab enters the mantle transition zone beneath the Okinawa Basin. The subducting Philippine slab steepened and deepened, gradually extending to the transition zone and lying above the detached Pacific slab. The continuous retreat of the IBM Trench facilitated horizontal subduction of the Pacific slab in the mantle transition zone (Figure 8B). According to the consistency between the mantle flow models and seismic images, we suggest that the small subslab-2 corresponds to the detached Pacific slab. The gap between subslab-1 and subslab-2 resulted from the establishment of IBM subduction behind the Ryukyu Trench, while the gap or necking between subslab-2 and subslab2A may have resulted from the delayed tearing of the Pacific slab after approaching the PSP at the surface and westward mantle flow in the mantle transition zone. In comparing this model Case 1-1 with the model of Ma et al. (2019), we found that the latter was unable to simulate the detailed detachment and tearing of the Pacific slab during the Miocene with the lack of constraints on the subducted Pacific slab and PSP above $350 \mathrm{~km}$ beneath the East Asian margin.

When the horizontal Pacific slab architecture was produced in the mantle transition zone is another important issue. Through labeling and tracking particles (tracers) within the Pacific slabs subducted along the proto-Ryukyu and Japan Trenches in Case 1-1 (Ma et al., 2019), we further assessed the temporal movement of the horizontal slab and determined the length of time since the Pacific slab entered the mantle transition zone. We obtained a NNE-strike age distribution of the slab materials within the stagnant slab. The results suggest that the westernmost tip of the slab could have reached the area beneath the Yellow Sea basin at $32 \mathrm{Ma}$ and the area beneath the Bohai Bay basin at $18 \mathrm{Ma}$ (Figure 9B, C). Thus, these calculations suggest that it has been $42 \mathrm{Myr}$ since the slab material initially entered the transition zone

This article is protected by copyright. All rights reserved. 
(Figure 9) and that the horizontal slab within and the associated large mantle wedge beneath East Asia developed after Izanagi-Pacific ridge subduction.
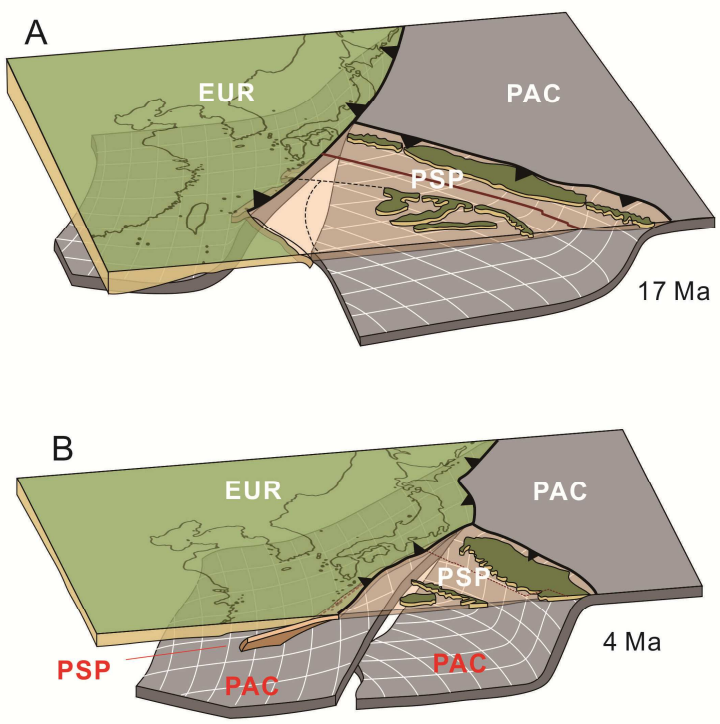

Figure 8. Stereograph exhibiting the geodynamic process associated with triple junction migration and Pacific slab tearing along the East Asian margin at $17 \mathrm{Ma}$ (A) and $4 \mathrm{Ma}$ (B). The other symbols are the same as those in Figure 1.

The origin of the large horizontal Pacific slab within the transition zone is controversial (Mao and Zhong, 2018; Ma et al., 2019). Previous studies emphasized the influence of a viscosity jump, mineral phase transitions, shallow-dipping subduction and trench retreat on the formation of the horizontal slab beneath East Asia (Mao and Zhang, 2019). Our mantle flow models further confirmed the role of trench retreat (Figure S1) with viscosity jumps and phase transitions across the 660-km discontinuity in preventing the slabs from instantly sinking into the lower mantle. Notably, a broad northwestward flow of the ambient mantle in the transition zone and the upper lower mantle, driven by accumulated negative buoyancy from subduction since the Mesozoic, should have contributed to shaping the prolonged horizontal subduction and presentday horizontal slab morphology (Figure 7; Figure S8). Mesozoic subduction of the Izanagi plate induced local downwelling below East Asia, which could have facilitated the partial penetration of the Pacific slab into the lower mantle (Figure 7; Figure S8). The new computations verify the utility of detailed plate reconstruction in forming the mantle architecture (Figure 3). We suspect that the slab segmentation associated with triple junction migration also affected the horizontal architecture of the slabs (Figure 7 and Figure S8).

This article is protected by copyright. All rights reserved. 

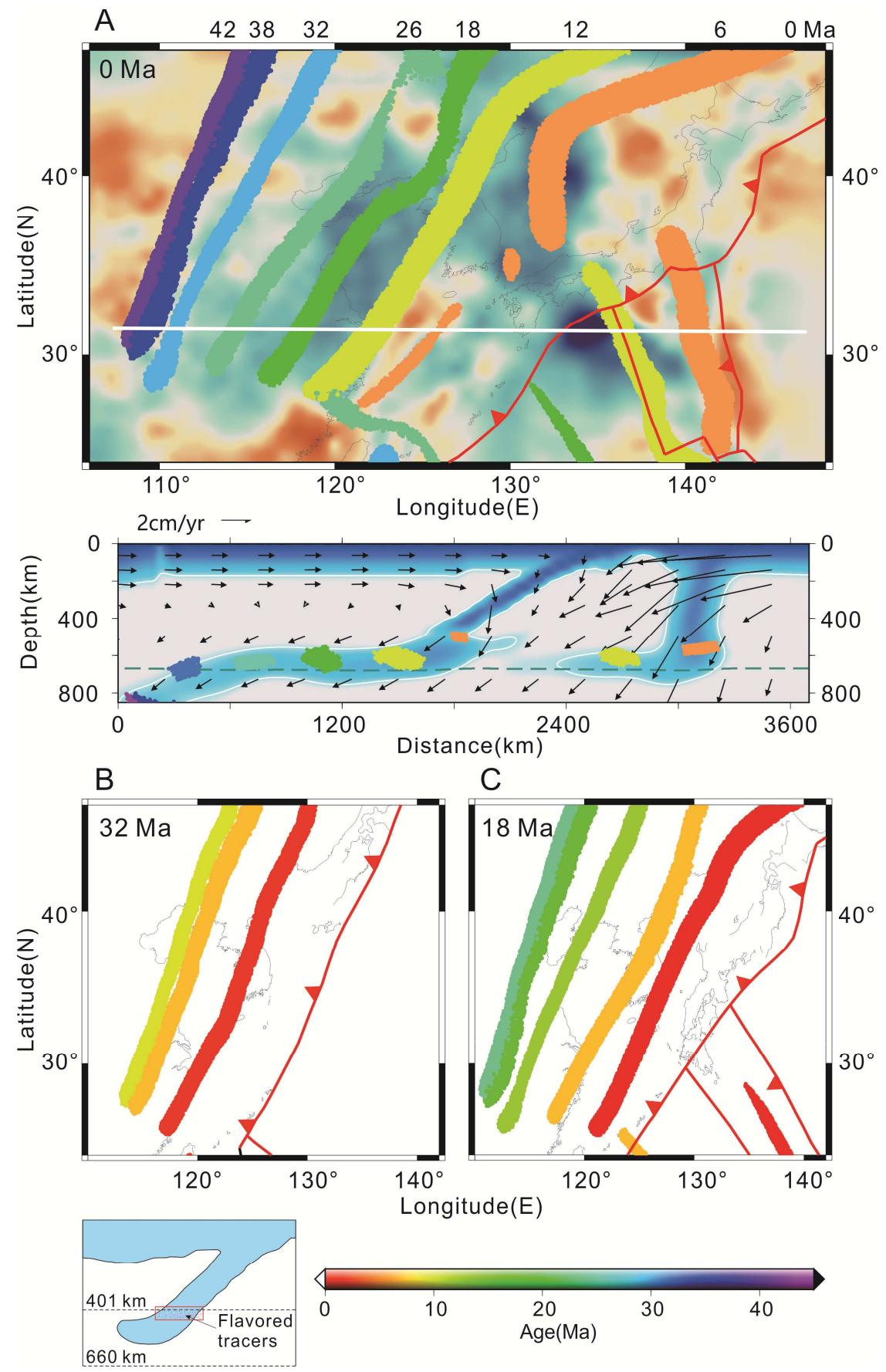

Figure 9. Predicted stagnation age of the Pacific slab subducted in the transition zone below East Asia in map view and cross-section at present (a) and in map view at $32 \mathrm{Ma} \mathrm{(b)} \mathrm{and} \mathrm{at} 18 \mathrm{Ma}$ (c). The zonation of belts is indicated by projections of the labeled tracers inside the subducted slab material, which are colored in light of their stagnation ages in the transition zone. The inset figure is a conceptual map to show the seasoning of the tracers.

This article is protected by copyright. All rights reserved. 
Earth's surface dynamic topography is a record of mantle convection and mantle viscous drag driven by slab subduction below the lithosphere. The evolving dynamic topography computed by mantle flow model Case 1-1 generally fits the evolution of the residual topography from 17 points in the Bohai Bay and Yellow Sea basins, but Case 3-1, which further confirms our modeled dynamic topography results. Generally, the predicted dynamic topography is closely related to the space-time changes in slab subduction and triple junction migration along the East Asian margin (Figure 10; Figure S7). From the Eocene (46 Ma) to the early Oligocene (31 Ma), the pattern of dynamic topography is characterized by a nearly N-S pattern with negative dynamic topography that parallels the subduction zones along the East Asian margin. However, the amplitude decreases within the onshore region. In the early Miocene (from $22 \mathrm{Ma}$ to $15 \mathrm{Ma}$ ), broad dynamic topographic lows with amplitudes greater than $-600 \mathrm{~m}$ with a subsidence center developed behind the subduction zones reflect the negatively buoyant drag of wide horizontally subducting slabs in the transition zone below the ECS and West Philippine Sea basin. From the late Miocene to the present day ( $8 \mathrm{Ma}$ to $0 \mathrm{Ma}$ ), the dynamic topographic lows behind the proto-Ryukyu subduction zone have gradually changed into wide subduction troughs with increasing subsidence amplitude. These deeper and wider troughs resulted from overlapping of the subducted PSP and detached Pacific slab and the westward shift of the detached Pacific slab in the transition zone.

The dynamic uplift and subsidence events near the Bohai Bay and Yellow Sea basins ca. $65 \mathrm{Ma}, 50-45 \mathrm{Ma}, 40-30 \mathrm{Ma}$, and 20-15 Ma, and the present day records the entire plate subduction process (Figure S7). The early dynamic subsidence ca. 65 Ma resulted from Izanagi plate subduction, and the transition from high subsidence to low subsidence (effective uplift) at 50-45 Ma resulted from subduction of the Izanagi-Pacific oceanic ridge at approximately $55 \mathrm{Ma}$ in the reconstruction. The subduction of the Pacific Plate into the transition zone at 40-30 Ma drove the initial large dynamic subsidence near the Bohai Bay Basin, while its sinking across the 660-km phase transition boundary beneath the basin induced dynamic uplift at 20-15 Ma. The nearly horizontal slab was generally stable within the transition zone on the present day, although it moved horizontally in the model. In some models, the slab begins to sink into the lower mantle, and the dynamic topography slightly increases above the leading edge of the horizontal slab. Regionally, since ca. 8-5 Ma, the whole East Asian margin was situated over a large-amplitude dynamic topography low (Figures 7 and 10). From the broader perspective, marine inundations and retreats have been minor, as evident in global paleogeographic maps (Smith et al., 1994) or in differential motions inferred from those maps (Spasojevic and Gurnis, 2012). Consequently, East Asia is not expected to have been strongly affected by dynamic topography, which is consistent with the general stability of flat slabs in the transition zones in the new models. However, the dynamic topography driven by wide horizontal slab subduction has made an important contribution to the low relief and shallow marine inundation into Bohai Bay in the East Asian margin since ca. 5 Ma. This dynamic topographic low, together with episodic rifting triggered by trench retreat (Liu et al., 2017), may contribute to the formation of the lowlands east of the Jianghan, Bohai Bay, and Songliao basins and the gravity gradient belt (50-80 km wide) along the western margin of the basins (Fig. 1). The residual subsidence inferred from the predicted isostatic topography and the observed tectonic subsidence over the last 50 Myr varies by only approximately \pm 200 meters during a period of no large marine inundation or retreat. The dynamic topography over the last 50 million years from those models that fit the horizontal slab in the mantle also predicts a rather subdued change in dynamic topography that is consistent with the stratigraphic record.

This article is protected by copyright. All rights reserved. 

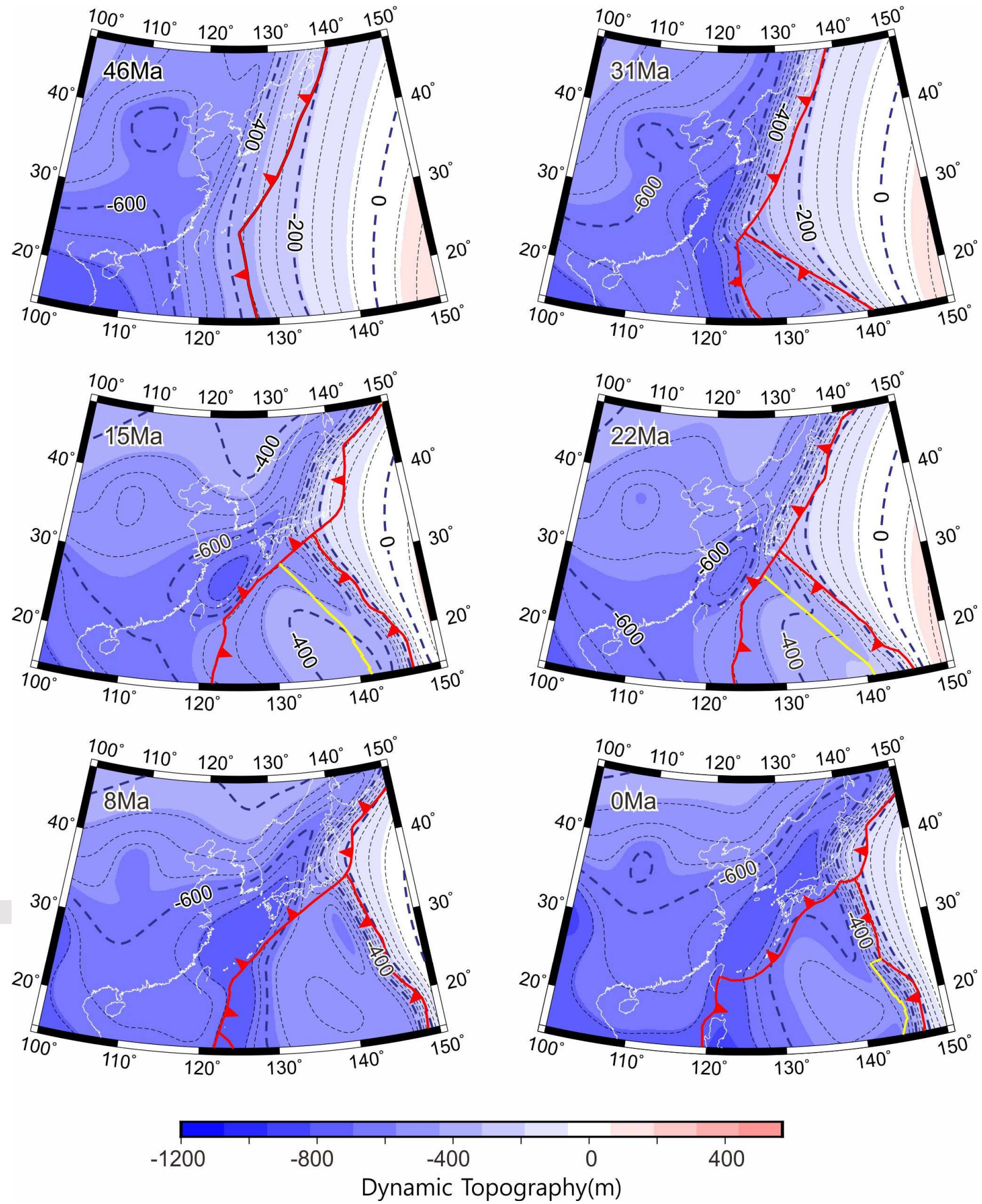

Figure 10. Maps showing the evolution of the dynamic topography predicted by Case 1-1. The thick red lines and the thick yellow lines represent subduction zones and faults and seafloor

This article is protected by copyright. All rights reserved. 
spreading centers, respectively. Coastlines are shown with white lines. The map area and location are the same as those in Figure 1.

In contrast, Southeast Asia behind subduction zones underwent large-scale continental inundation during the Miocene (Zahirovic et al., 2016; Spasojevic and Gurnis, 2012). Sundaland, the continental core of Southeast Asia, developed extensive rift basins and has undergone strong stretching since the Eocene. However, starting in the early Miocene, the basins in southern Sundaland were inverted with broad compression and synchronous marine inundation (Hall and Morley, 2004; Doust and Sumner, 2007) despite long-term global sea level fall. The reason why this opposite tectonic evolution trend with regional sea-level rise, high subsidence rate, and basin inversion in the postrifting period occurred in these basins was suggested by Yang et al. (2016). Their geodynamic mantle flow models with both deforming plate and rigid plate reconstructions, similar to those presented here for East Asia, indicate that a stagnant slab subducted within the mantle transition zone below Southeast Asia before the Miocene and that this horizontal subduction may have triggered rifting and extension in Southeast Asia, similar to what we have modeled in the East Asian margin since 54 Ma. Particularly, these models show that the stagnant slab passed through the 660-km discontinuity and that a slab avalanche event was produced because of continuous downwelling induced by subduction of negatively buoyant slabs during the early Miocene. Yang et al. (2016) argue that this slab avalanche may have triggered basin inversion with rapid subsidence and large-scale marine inundation across southern Sundaland. We conjecture that the flat slab within the mantle transition zone that we now see below East Asia is similar to what the slabs would have been like below Southeast Asia before the early Miocene. This is consistent with the generally subduced dynamic topography and widely rifted low elevations that we infer for East Asia during the Cenozoic. However, the tectonics and topography of East Asia strongly contrast with those of Southeast Asia during the early Miocene and are reflective of slabs ephemerally stagnating in the mantle below East Asia while avalanching into the lower mantle below Southeast Asia. This avalanche event may occur in the future beneath the East Asian margin.

\section{Conclusions}

In summary, our results show a detailed four-dimensional reconstruction of the platemantle system in East Asia since 54 Ma using combined forward modeling of deforming plate motion and mantle convection. Below are our main conclusions.

(1) the new deforming plate reconstruction during the Cenozoic depicts the evolving plate boundaries and plate deformation, including northward PSP motion with oblique convergence between the PSP and the Eurasian plate, northward TTT triple junction migration, eastward retreat of the Japan, Nankai, and Ryukyu trenches, and northeastward retreat of the IBM trench. The results of this reconstruction provide detailed kinematic constraints on four-dimensional plate-mantle models of East Asia.

(2) the forward mantle flow models constrained by updated deforming plate reconstructions essentially fit major features in seismic tomography images beneath East Asia. Specifically, significant tearing propagated through the subducted western Pacific slab as the PSP rotated clockwise starting in the Oligocene, leading to internal slab segmentation and

This article is protected by copyright. All rights reserved. 
detachment. A broad northwestward flow of the ambient mantle driven by accumulated negative buoyancy contributed to shaping horizontal subduction, although slab tearing and trench retreat also influenced the horizontal configuration of the slabs. The stagnation age, i.e., the time since the horizontal slab entered the mantle transitional zone beneath the Bohai Bay basin, is about 42 Ma.

(3) the dynamic topography generated by the mantle flow models with amplitudes of about \pm 200 meters, mostly fit present-day residual topography and variation in residual subsidence over the last 50 Myr. The evolution of dynamic topography in the East Asian margin, driven by horizontal slab subduction and slab tearing in the mantle, represents an important control on the formation of low relief in East Asia.

(4) the wide horizontal slab beneath East Asia and the associated dynamic topography low have led to the formation of a gravity gradient belt along the western margin of the Jianghan, Bohai Bay, and Songliao basins. The dynamic topography of East Asia contrasts with that of Southeast Asia and is reflective of slabs ephemerally stagnating in the mantle below East Asia while avalanching into the lower mantle below Southeast Asia.

\section{Acknowledgments, Samples, and Data}

- No financial conflicts of interests for any author of this paper.

- No any other affiliation for any author that may be perceived as having a conflict of interest with respect to the results of this paper.

- Datasets for this research are available in these in-text data citation references: Müller et al. (2016), Zahirovic et at. (2016), Liu et al. (2017), Ma et al. (2019). We will deposit our data at the Caltech Data Repository (https://data.caltech.edu/), a repository maintained by the Caltech Library in which all content is indefinitely retained.

- This work was funded by the Strategic Priority Research Program (B) of the Chinese Academy of Sciences (Grant No. XDB18000000), National Natural Science Foundation of China grants (Nos. 41820104004, 91114203, and 41572189), the National Key R\&D Plan (Grant No. 2017YFC0601405), and the US National Science Foundation (EAR1645775). We thank D. Müller and S. Zahirovic for generously sharing the age grid software; D. Bower, N. Flament, and L. J. Liu for valuable discussions on the dataassimilation method; W. Leng and T. Yang for assistance with CitcomS; Z. Yinbing and Y. Xiang for sharing their residual data. We also thank Drs. F. A. Capitanio, A. Schettino, and an anonymous reviewer for their very detailed reviews and constructive comments. Computations were performed at the Geodynamic Modeling Lab (GML), China University of Geosciences (Beijing).

\section{References}

Amano, K. (1991). Multiple collision tectonics of the South Fossa Magna in central Japan. Modern Geology, 15, 315-329.

This article is protected by copyright. All rights reserved. 
Asamori, K., Zhao, D. (2015). Teleseismic shear wave tomography of the Japan subduction zone. Geophysical Journal International, 203(3), 1752-1772.

Billen, M.I. (2010). Slab dynamics in the transition zone. Physics of The Earth and Planetary Interiors, 183(1-2), 296-308.

Bower, D.J., Gurnis, M., \& Flament, N. (2015). Assimilating lithosphere and slab history in 4-D Earth models. Physics of The Earth and Planetary Interiors, 238, 8-22.

Celaya, M. \& McCabe, R. (1987). Kinematic model for the opening of the sea of Japan and the bending of the Japanese islands. Geology, 15(9), 53-57.

Christensen, U. R. (1996). The influence of trench migration on slab penetration into the lower mantle. Earth and Planetary Science Letters, 140(1-4), 27-39.

Čížková, H., \& Bina, C.R. (2015). Geodynamics of trench advance: Insights from a PhilippineSea-style geometry. Earth and Planetary Science Letters, 430, 408-415.

DeMets, C., Gordon, R.G. \& Argus, D.F. (2011). Geologically current plate motions. Geophysical Journal International, 187(1), 538-538.

Deschamps, A. \& Lallemand, S. (2002). The West Philippine Basin: An Eocene to early Oligocene back arc basin opened between two opposed subduction zones. Journal of Geophysical Research: Solid Earth, 107(B12), 2322.

Deschamps, A., Monie, P., Lallemand, S., Hsu, S.K. \& Yeh, K.Y. (2000). Evidence for Early Cretaceous oceanic crust trapped in the Philippine Sea Plate, Earth and Planetary Science Letters, 179(3-4), 503-516.

Doust, H., \& Sumner, H.S. (2007). Petroleum systems in rift basins-A collective approach in Southeast Asian basins. Petroleum Geoscience, 13(2), 127-144.

Faccenna, C., Becker, T.W., Miller, M.S., Serpelloni, E., \& Willett, S.D. (2014). Isostasy, dynamic topography, and the elevation of the Apennines of Italy. Earth and Planetary Science Letters, 407, 163-174.

Faccenna, C., Holt, A., Becker, T., Lallemand, S., \& Royden, L. (2018). Dynamics of the Ryukyu/Izu-Bonin-Marianas double subduction system. Tectonophysics, 746(S1), 229-238.

Flament, N., Gurnis, M., \& Müller, R.D. (2013). A review of observations and models of dynamic topography. Lithosphere,5(2), 189-210.

Flament, N., Gurnis, M., Williams, S., Seton, M., Skogseid, J., Heine, C., \& Müller, R.D. (2014). Topographic asymmetry of the South Atlantic from global models of mantle flow and lithospheric stretching. Earth and Planetary Science Letters, 387, 107-119.

Fukao, Y. \& Obayashi, M. (2013). Subducted slabs stagnant above, penetrating through, and trapped below the $660 \mathrm{~km}$ discontinuity. Journal of Geophysical Research Solid Earth, 118(11), 5920-5938.

Fukao, Y., Obayashi, M., Inoue, H., \& Nenbai, M. (1992). Subducting slabs stagnant in the mantle transition zone. Journal of Geophysical Research: Solid Earth, 97(B4), 4809-4822.

Goes, S., Agrusta, R., van Hunen, J., \& Garel, F. (2017). Subduction-transition zone interaction: A review. Geosphere, 13(3): 644-664.

This article is protected by copyright. All rights reserved. 
Gurnis, M., Turner, M., Zahirovic, S., DiCaprio, L., Spasojevic, S., Müller, R.D., Boyden, J., Seton, M., Manea, V.C., \& Bower, D.J. (2012). Plate tectonic reconstructions with continuously closing plates. Computers \& Geosciences, 38(1), 35-42.

Gurnis, M., Yang, T., Cannon, J., Turner, M., Williams, S., Flament, N., \& Müller, R.D. (2018). Global tectonic reconstructions with continuously deforming and evolving rigid plates.

Computers \& Geosciences, 116, 32-41.

Hager, B.H. (1984). Subducted slabs and the geoid: Constraints on mantle rheology and flow. Journal of Geophysical Research, 89(NB7), 6003-6015.

Hall, R. \& Morley, C.K. (2004). Sundaland basins. In P. Clift, W. Kuhnt, P. Wang, \& D. Hayes (eds.), Continent-Ocean Interactions within East Asian Marginal Seas (pp. 55-85), Geophysical Monograph Series, AGU, Washington, D. C.

Han, L. \& Gurnis, M. (1999). How valid are dynamic models of subduction and convection when plate motions are prescribed? Physics of The Earth and Planetary Interiors, 110(3-4), 235246.

Haston, R.B. \& Fuller, M. (1991). Paleomagnetic data from the Philippine Sea plate and their tectonic significance. Journal of Geophysical Research: Solid Earth and Planets, 96(B4), 60736098.

Hickey-Vargas, R. (2005). Basalt and tonalite from the Amami Plateau, northern West Philippine Basin: New Early Cretaceous ages and geochemical results, and their petrologic and tectonic implications. Island Arc, 14(4), 653-665.

Hoggard, M., Winterbourne, J., Czarnota, K., \& White, N. (2017). Oceanic residual depth measurements, the plate cooling model, and global dynamic topography. Journal of Geophysical Research: Solid Earth, 122(3), 2328-2372.

Holt, A.F., Royden, L.H., Becker, T.W. \& Faccenna, C. (2018). Slab interactions in 3-D subduction settings: The Philippine Sea Plate region. Earth and Planetary Science Letters, 489, $72-83$.

Huang, J. \& Zhao, D. (20060. High-resolution mantle tomography of China and surrounding regions. Journal of Geophysical Research: Solid Earth, 111(B6), B09305.

Ishizuka, O., Tani, K., Reagan, M.K., Kanayama, K., Umino, S., Harigane, Y., Sakamoto, I., Miyajima, Y., Yuasa, M. \& Dunkley, D.J. (2011). The timescales of subduction initiation and subsequent evolution of an oceanic island arc. Earth and Planetary Science Letters, 306(3-4), 229-240.

Kimura, J.I., Stern, R.J. \& Yoshida, T. (2005). Reinitiation of subduction and magmatic responses in SW Japan during Neogene time. Geological Society of America Bulletin, 117(7-8), 969-986.

Kimura, G., Hashimoto, Y., Kitamura, Y., Yamaguchi, A. \& Koge, H. (2014). Middle Miocene swift migration of the TTT triple junction and rapid crustal growth in southwest Japan: A review. Tectonics, 33(7), 1219-1238.

This article is protected by copyright. All rights reserved. 
Lallemand, S., Font, Y., Bijwaard, H. \& Kao, H. (2001). New insights on 3-D plates interaction near Taiwan from tomography and tectonic implications. Tectonophysics, 335(3-4), 229-253.

Lallemand, S., Jolivet, L., 1986. Japan sea - a pull-apart basin. Earth Planet. Sci. Lett. 76, 375389.

Leng, W. \& Gurnis, M. (2015). Subduction initiation at relic arcs. Geophysical Research Letter, 42(17), 7014-7021.

Li, C. \& van der Hilst, R.D. (2010). Structure of the upper mantle and transition zone beneath Southeast Asia from traveltime tomography. Journal of Geophysical Research: Solid Earth, 115, B07308.

Li, C., van der Hilst, R.D., Engdahl, E.R. \& Burdick, S. (2008). A new global model for P wave speed variations in Earth's mantle. Geochemistry Geophysics Geosystems, 9, Q05018.

Li, Z.H., Gerya, T., Connolly, J.A.D. (2019). Variability of subducting slab morphologies in the mantle transition zone: Insight from petrological-thermomechanical modeling. Earth-Science Reviews, 196, 102874.

Lin, A.T., Watts, A. B., Hesselbo, S. P., 2003. Cenozoic stratigraphy and subsidence history of the South China Sea margin in the Taiwan region. Basin Res. 15, 453-478.

Liu, S.F., Gurnis, M., Ma, P.F. \& Zhang, B. (2017). Reconstruction of northeast Asian deformation integrated with western Pacific plate subduction since 200 Ma. Earth-Science Reviews, 175, 114-142.

Liu, S.F., Lin, C.F., Liu, X.B. \& Zhuang, Q.T. (2018). Syn-tectonic sedimentation and its linkage to fold-thrusting in the region of Zhangjiakou, North Hebei, China. Science China: Earth Sciences, 61 (6): 681-710.

Liu, S.F. \& Nummedal, D. (2004). Late Cretaceous subsidence in Wyoming: Quantifying the dynamic component. Geology, 32(5), 397-400.

Liu, S.F., Nummedal, D. \& Liu, L.J. (2011). Migration of dynamic subsidence across the Late Cretaceous United States Western Interior Basin in response to Farallon plate subduction. Geology, 39(6), 555-558.

Ma, P.F., Liu, S.F., Gurnis, M. \& Zhang, B. (2019). Slab horizontal subduction and slab tearing beneath East Asia. Geophysical Research Letters, 46(10), 5161-5169.

Mao, W. \& Zhong, S. (2018). Slab stagnation due to a reduced viscosity layer beneath the mantle transition zone. Nature Geoscience, 11(11), 876-881.

Mckenzie, D., 1978. Some remarks on the development of sedimentary basins. Earth and Planetary Science Letter, 40, 25-32.

Miki, M., 1995. Two-phase opening model for the Okinawa Trough inferred from paleomagnetic study of the Ryukyu arc. Journal of Geophysical Research-Solid Earth, 100, 8169-8184.

Miller, M.S. \& Kennett B.L.N. (2006). Evolution of mantle structure beneath the northwest Pacific: Evidence from seismic tomography and paleogeographic reconstructions. Tectonics, 25(4), TC4002.

Müller, R.D., Seton, M., Zahirovic, S., Williams, S.E., Matthews, K.J., Wright, N.M., Shephard, E.G., Maloney, T.K., Barnett-Moore, N., Hosseinpour, M., Bower, J.D. \& Cannon, J. (2016).

This article is protected by copyright. All rights reserved. 
Ocean basin evolution and global-scale plate reorganization events since Pangea breakup. Annual Review of Earth and Planetary Sciences, 44, 107-138.

Müller, R.D., Zahirovic, S., Williams, S., Cannon, J., Seton, M., Bower, D., Tetley, M., Heine, G., Breton, E.L., Liu, S.F., Russell, S.H.J., Yang, T., Leonard, J. \& Gurnis, M. (2019). A global plate model including lithospheric deformation along major rifts and orogens since the Triassic. Tectonics, 38(6), 1884-1907.

Nishizawa, A., Kaneda, K., Katagiri, Y., Oikawa, M., 2014. Wide-angle refraction experiments in the Daito Ridges region at the northwestern end of the Philippine Sea plate. Earth Planets Space 66, 10.1186/1880-5981-66-25.

Otofuji, Y. I., 1996. Large tectonic movement of the Japan Arc in late Cenozoic times inferred from paleomagnetism: Review and synthesis. Island Arc 5, 229-249.

Raimbourg, H., Augier, R., Famin, V., Gadenne, L., Palazzin, G., Yamaguchi, A. \& Kimura, G. (2014). Long-term evolution of an accretionary prism: The case study of the Shimanto Belt, Kyushu, Japan. Tectonics 33(6), 936-959.

Raimbourg, H., Famin, V., Palazzin, G., Yamaguchi, A. \& Augier, R. (2017). Tertiary evolution of the Shimanto belt (Japan): A large-scale collision in Early Miocene. Tectonics, 36(7), 13171337.

Reagan, M. K., Heaton, D. E., Schmitz, M. S., Pearce, J. A., Shervais, J. W., and Koppers, A. P. (2019). Forearc ages reveal extensive short-lived and rapid seafloor spreading following subduction initiation. Earth and Planetary Science Letters, 506, 520-529, https://www.sciencedirect.com/journal/earth-and-planetary-science-letters/vol/506/suppl/C.

Salzea, M., Martinod, J., Guillaumec, B., Kermarrec, J.J., Ghiglione, M.C. \& Sue, C. (2018). Trench-parallel spreading ridge subduction and its consequences for the geological evolution of the overriding plate: Insights from analogue models and comparison with the Neogene subduction beneath Patagonia. Tectonophysics, 737, 27-39.

Seno, T. \& Maruyama, S. (1984). Paleogeographic reconstruction and origin of the Philippine Sea. Tectonophysics, 102(1), 53-84.

Seno, T., Stein, S. \& Gripp, A.E. (1993). A model for the motion of the Philippine Sea Plate consistent with NUVEL-1 and geological data. Journal of Geophysical Research: Solid Earth, 98(B10), 17941-17948.

Seton, M., Müller, R.D., Zahirovic, S., Gaina, C., Torsvik, T., Shephard, G., Talsma, A., Gurnis, M., Turner, M., Maus, S. \& Chandler, M. (2012). Global continental and ocean basin reconstructions since 200 Ma. Earth-Science Reviews, 113, 212-270.

Shinjo, R. (1999). Geochemistry of high Mg andesites and the tectonic evolution of the Okinawa Trough-Ryukyu arc system. Chemical Geology, 157(1), 69-88.

Sibuet, J.C., Hsu, S.K., Shyu, C.T. \& Liu, C.S. (1995). Structural and Kinematic Evolutions of the Okinawa Trough Backarc Basin. In B. Taylor (ed.), Backarc Basins: Tectonics and Magmatism (pp. 343-379). Springer US, Boston, MA.

Smith, A.G., Smith, D.G. \& Funnel, B.M. (1994). Atlas of Mesozoic and Cenozoic coastlines (New York, Cambridge University Press).

This article is protected by copyright. All rights reserved. 
Spasojevic, S. \& Gurnis, M. (2012). Sea level and vertical motion of continents from dynamic Earth models since the Late Cretaceous, AAPG Bulletin, 96(11), 2037-2064.

Su, J., Zhu, W., Chen, J., Ge, R., Zheng, B. \& Min, B. (2014). Cenozoic inversion of the East China Sea Shelf Basin: implications for reconstructing Cenozoic tectonics of eastern China. International Geology Review, 56(12), 1541-1555.

Tamayo, J.R.A., Maury, R.C., Yumul, J. G. P., Polvé, M., Cotten, J., Dimantala, C.B. \& Olaguera, F.O. (2004). Subduction-related magmatic imprint of most Philippine ophiolites: implications on the early geodynamic evolution of the Philippine archipelago. Bulletin de la Société Géologique de France, 175(5), 443-460.

Tao, K., Grand, S. \& Niu, F. (2018). Seismic structure of the upper mantle beneath Eastern Asia from full waveform seismic tomography. Geochemistry Geophysics Geosystems, 19(8), 27322763.

Wei, W., Xu, J., Zhao, D. \& Shi, Y. (2012). East Asia mantle tomography: New insight into plate subduction and intraplate volcanism. Journal of Asian Earth Sciences, 60, 88-103.

White, N. (1994). An inverse method for determining lithospheric strain rate variation on geological timescales. Earth and Planetary Science Letters, 122(3-4), 351-371.

Wortel, R., Govers, R. \& Spakman, W. (2009). Continental Collision and the STEP-wise Evolution of Convergent Plate Boundaries: From Structure to Dynamics. In S. Lallemand, F. Funiciello (Eds.), Subduction Zone Geodynamics (pp. 47-59). Springer.

Wu, F.Y., Yang, J.H., Xu, Y.G., Wilde, A.S. \& Walker J.R. (2019). Destruction of the North China Cratone in the Mesozoic. Annual Review of Earth and Planetary Sciences, 47: 173-195.

Wu, J., Suppe, J., Lu, R. \& Kanda, R. (2016). Philippine Sea and East Asian plate tectonics since 52 Ma constrained by new subducted slab reconstruction methods. Journal of Geophysical Research: Solid Earth, 121(6), 4670-4741.

Yang, T., Gurnis, M. \& Zahirovic, S. (2016). Mantle-induced subsidence and compression in SE Asia since the early Miocene. Geophysical Research Letters, 43(5), 1901-1909.

Yang, T., Moresi, L., Gurnis, M., Liu, S.F., Sandiford, D., Williams, S. \& Capitanio, F.A. (2019). Contrasted East Asia and South America tectonics driven by deep mantle flow. Earth and Planetary Science Letters, 517, 106-116.

Yao, X., Liu, S.F., Bai, Y. \& Ji, H. (2017). Neogene residual subsidence and its response to a sinking slab in the deep mantle of eastern China. Journal of Asian Earth Sciences, 143, 269-283.

Yumul, G.P., Dimalanta, C.B., Tamayo, R.A. \& Maury, B.C. (2003). Collision, subduction and accretion events in the Philippines: A synthesis. Island Arc, 12(2), 77-91.

Zahirovic, S., Matthews, K.J., Flament, N., Müller, R.D., Hill, K.C., Seton, M. \& Gurnis, M. (2016). Tectonic evolution and deep mantle structure of the eastern Tethys since the latest Jurassic. Earth-Science Reviews, 162, 293-337.

Zheng, T., Chen, L., Zhao L., Xu, W., \& Zhu, R. (2006). Crust-mantle structure difference across the gravity gradient zone in North China Craton: Seismic image of the thinned continental crust. Physics of the Earth and Planetary Interiors, 159, 43-58.

This article is protected by copyright. All rights reserved. 
Zhong, S. \& Gurnis, M. (1995). Mantle convection with plates and mobile, faulted plate margins. Science, 267, 838-843.

Zhong, S., McNamara, A., Tan, E., Moresi, L. \& Gurnis, M. (2008). A benchmark study on mantle convection in a $3 \square \mathrm{D}$ spherical shell using CitcomS. Geochemistry Geophysics Geosystems, 9, Q10017.

Zhu, G., Shi, Y. \& Tackley, P. (2010). Subduction of the Western Pacific Plate underneath Northeast China: Implications of numerical studies. Physics of the Earth and Planetary Interiors, 178(1-2), 92-99 (2010).

Zhu, Y.B., Liu, S.F., Zhang, B., Gurnis, M. \& Ma, P.F. (2020). Reconstruction of the Cenozoic deformation of the Bohai Bay Basin, North China. Basin Research, DOI: 10.1111/bre.12470.

This article is protected by copyright. All rights reserved. 